BUREAU OF ECONOMIC GEOLOGY

The University of Texas

Austin 12, Texas

JOHN T. LONSDALE, Director

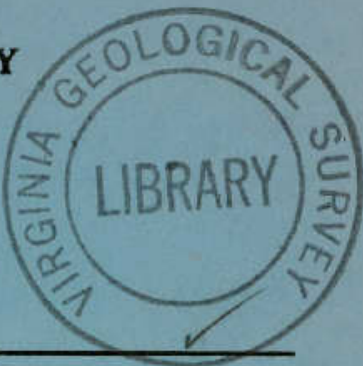

Report of Investigations-No. 12

\title{
Geology of the Blacklands Experimental Watershed, Near Waco, Texas
}

\author{
By \\ HORACE R. BLANK, NORVAL L. STOLTENBERG, AND \\ HARRY H. EMMERICH
}

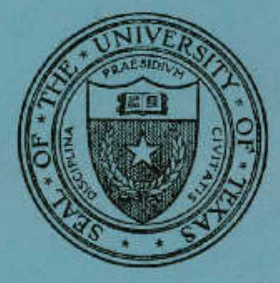

March 1952 



\title{
BUREAU OF ECONOMIC GEOLOGY
}

The University of Texas

Austin 12, Texas

JOHN T. LONSDALE, Director

Report of Investigations-No. 12

\section{Geology of the Blacklands Experimental Watershed, Near Waco, Texas}

\author{
By \\ HORACE R. BLANK, NORVAL L. STOLTENBERG, AND
}

HARRY H. EMMERICH

March 1952 
$\because 34 . \therefore$. तA 
Abstract

Introduction

Location and history

Acknowledgments

General features of the experimental watershed

Climate and agriculturs

Geology

Topography

Drainage

Rocks of the experimental watershed

Wolfe City member of Taylor mat

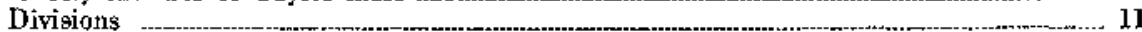

Sandy marl

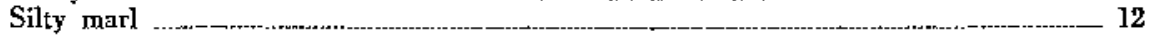

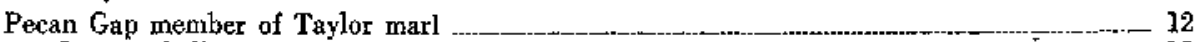

Lower chalk _._. 12

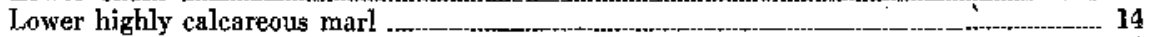

Upper chalk _

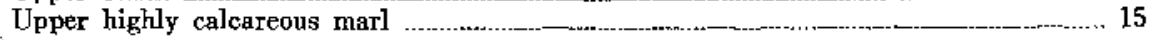

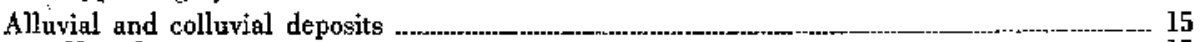

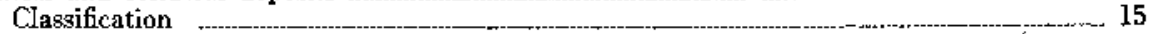

Upland gravel (Uvalde formation) _ 16

Terraces of the Brazos River _...

Terrace alluvium along Brushy Creek and adjacent streams

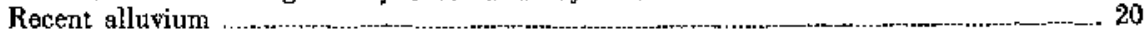

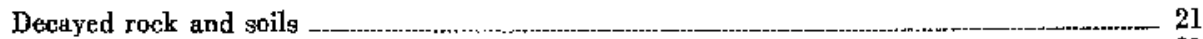

Decay of the rocks _.__

Relation between parent rocks and soils

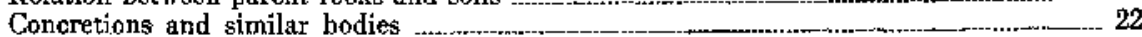

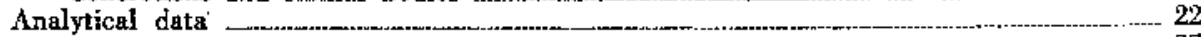

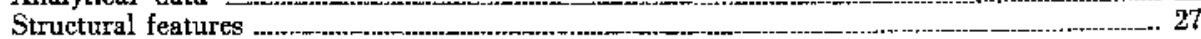

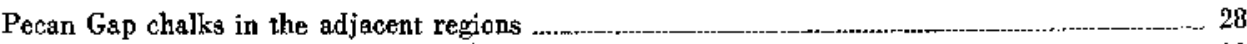

References _.._-__-_._- 33

Appendix _......._- 34

Well data

Hole 694 _.......... 34

Hole 1000 -

Hole 1010 -

Hole 1011 - 37

Hole 1012 -

Hole 1020 …n-_- 42

Index

1. Index map of Texas showing location of the Blacklands Expetimental Watershed......_- 6

Plates-

I. Geologic map of Blacklands Experimental Watershed, near Waco, Texas..........._. In pocket

II. Boundary between Pecan Gap and Wolfe City formations in parts of McLennan and Falls

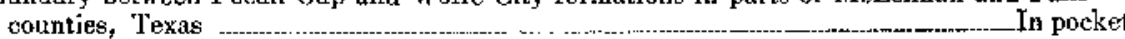

III. Contact of Pecan Gap chalk with Wolfe City silty marl, showing soft white calciım carbonate leached from the chalk and deposited in crevices in the marl._..Facing p. 22

IV. Contact of Pecan Gap chalk with Wolfe City silty marl. Chalk overlain by alluvium.......

Facing p. 27

\section{TABLES}

1. Geologic units at the Blacklands Experimental Watershed ________— 10

2. Description of samples analyzed ......... 24

3. Partial chemical analyses of rock materials - 25

4. Mechanical analyses of insolable residues from acid treatment of rock materials_-_-_-- 25 


\title{
GEOLOGY OF THE BLACKLANDS EXPERIMENTAL WATERSHED, NEAR WACO, TEXAS ${ }^{1}$
}

\author{
Horace, R. Blank," Norval I., Stoltenberg, ${ }^{3}$ and IIarry H. Emmerich ${ }^{1}$
}

\section{ABSTRACT}

The Blacklands Experimental Water* shed, a hydrologic research project of the Soil Conservation Service located about 15 miles southeast of Waco, Texas, is un+ derlain by marls and chalks belonging to the Taylor group of the Gulf series of the Cretaceous system, which, in conformity with the general structure of the Culf Coastal Plain, dip east-southeastward at an angle a little steeper than the general slope of the land surface.

The lowest strata cropping out in the experimental watershed are part of the: Wolfe City member of the Taylor marl and consist of aboul 110 feet of sandy marl containing numerous small lenses of hard calcareous sandstone. They are transitional upward into about 40 feet of silty marl, in which the sand or silt is too fine to be visible to the unaided eye.

Overlying the silty marl is a stratum of hard chalk, 8 to 25 feet thick, belonging to the Pecan Gap member of the Taylor marl. There is some evidence, that the chalk-silty marl contact is an unconformity. 'This contact is the only easily identified straligraphic marker in the cxperimental area. The chalk is hard enough to have some effect on the topography and the soil depth and brittle enough to influence greatly the distribution of the ground water.

The chalk is transitional upward into 90 to 100 fect of highly calcareous marl. Near the southeast corner of the experimental area this marl grades upward into another zone of about 13 fect of soft chalk, which in turn passes transitionally upward into additional highly calcareous marl.

Remnants of an upland gravel, consisting merely of pebbles and cobbles scattered in the soil, occur on a few of the hilltops

1W/ork performed under a cooperative agreement between the Texas Agricultural Experintan Statitin and the Sinil Congersation Service, U. S. Dept. of Agriculture. Published witls the permission of the Soil Conserpation Service. U.S.19.A.

${ }^{2}$ Forinerly aqgociale reologiat, Soil Conyervation Serviec.

3Fmmorly junior. eail technologist, Soil Congervation Service.

${ }^{4}$ Formerly junior auil techonolngist, Suil Couscrvation Scruice. in the southwest corner of the experimental area and probably belong to the Uvalde (Pliocene?) formation. The valleys of Brushy Creek and its principal tributaries are parlly filled with terrace alluvium consisting entirely of transported marl mixed with sand and pebbles and believed to be Plcistocene in age. Near the present stream channels there are also deposits of Recent alluvium consisting chiefly of transported soil.

Partial chemical analyses and mechani: cal analyses of the acid-insoluble residues bring oul some of the differences between the Wolfe City, Pecan Gap, and alluvial formations, as well as differences between the oxidized and unweathered rocks. The intimate relation between the rocks and the distribution of the soil series is dis. cussed.

The boundary between the Pecan Gap lower chalk and the Wolfe City silty marl is traced from Big Creek ncar Mart through the experimental watershed to Brazos River southwest of Marlin. It is shown that most of the chalk outcrops in this region described by other investigators correspond to the less defirile upper chalk rather than to this lower zone. The Pecan Gap belt of outcrop as shown on the geologic map of Texas (Darton et al., 1.937) is too narrow and too far east to include both these chalks. At some places it has been based on the lower zone, at others on the upper.

\section{INTRODUCTION}

\section{LOCATION AND HistoRY}

The Blacklands Experimental Watershed lies partly in McLennan and partly in Falls County, Texas, about 15 miles south. east of Waco and between the towns of Riesel and Mart (fig. 1 and Pl. II). It is composed of farms totalling about 6,350 acres, 84.1 acres being owned by the Government. Most of this land forms the upper. part of the watershed of Brushy Creek, a tributary of Big Creek, which in turn is tributary to Brazos River. The project also includes the headwaters of a tributary of 
Brushy Creek which joins that stream outside the experimental area.

The experimental watershed was established in 1936 for the study of hydrologic problems as affected by agricultural practices within the general sphere of the Soil Conservation Service. ,This study was a part of the work of the Hydrologic Division of the Office of Research of the Soil Conservation Service in cooperation with the Texas Agricultural Experiment Station. Other cooperators under formal agreement were the U. S. Weather Bureau and the Division of Cotton Insect Damage of the

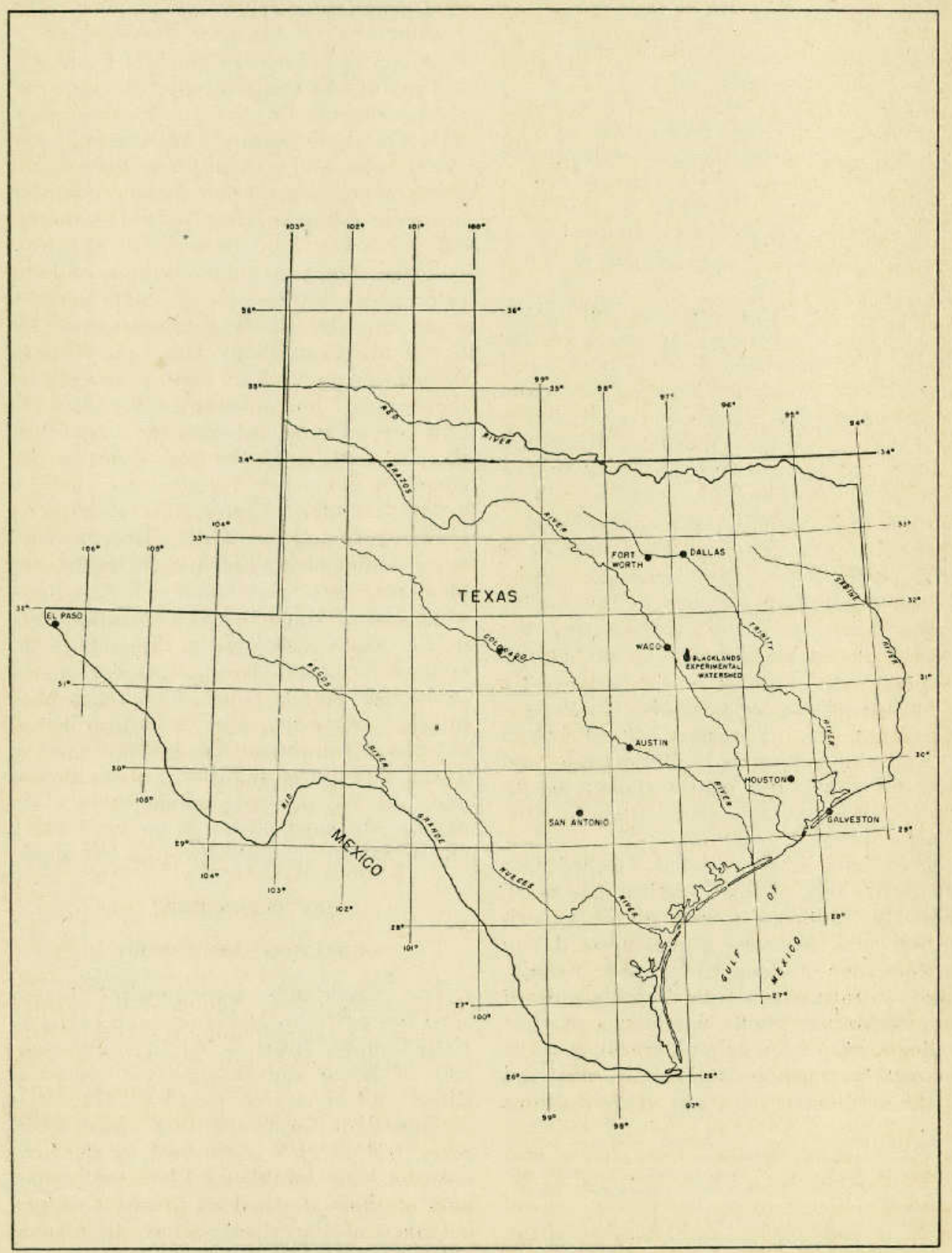

FIG. 1. Index map of Texas showing location of the Blacklands Experimental Watershed. 
U. S. Bureau of Entomology and Plant Quarantine.

Preliminary geologic studies of the region were made in connection with the selection of a suitable location for the experimental watershed early in 1936. When the project was established, more detailed studies of all outcrops occurring within the experimental area were made. Numerous auger holes were bored by hand labor throughout the area at various times between 1936 and 1940, many of which were cased with pipe and converted into observation wells for ground-water studies. Fuvorable rainfall conditions made possible more accurate surveys of the seeps along the lower edge of the Pecaur Gap chalk in 1.941, and this boundary was traced from the cxperimental area into the adjoining region at the same lime. Ground-water studies were carried on from 1936 to 1942.

A general description of the project and its work may be found in U. S. Department of Agriculture Iydrologic Bulletin 5 (Baird, Lauritzen, et al., 1942). Other publicalions giving data from the project are Hydrologic Bulletin 2 (Baird, Jenkins, et al., 1942) and ground-water graphs (Potter and Blank, 1939).

\section{ACKNOWLEDGMENTS}

Geology and ground-water studics at the experimental watershed were in charge of H. R. Blank from January to July 1.936 and from Oclober 1937 to their discon: tinuance in September 1942. N. L. Stoltenberg was continuously associated with the project from its beginning unlil January 1941 and was in active charge of the geology and ground-water work from July 1936 until October 1937, during which time he was assisted by H. H. Enmmerich.

Throughout the course of the work a great deal of assistance was recejved from all other members of the project staff. The geologic map (Pl. I) is based upon the topographic map of the experimental area made in 1936 by the project engineers. M. G. Santi, C. S. Bryan, and J. T. O'Brien survoyed most of the auger holes and wells. S. Folk, C. J. Thomason, and E. M. Lawhon assisted in the surveying, supervision of auger holes, and assembly of the data. A. J. Stewart and J. E. Poag carried out the mechanical analyses. The selection of the experimental watershed was under the supervision of D. B. Krimgold; after the establishment of the project all work was in charge of R. W. Baird, D. S. Jenkins, G. E. Byars, and L. A. Westby, successively project supervisors, under the general direction of .C. E. Ramser, chief, hydrologic division, and M. L. Nichols, chief of research, Soil Conservation Service.

The authors are also indebted for valuable assistance to the U. S. Geological Survey, the Department of Geology and the Bureau of Economic Ceology of The University of Texas, the Agricultural Adjustment Administration of Falls County, the Texas Highway Department engineers in McLennan and Falls counties, and the several landowners in the experimental watershed. Dr. L. W. Stephenson of the U. S. Geological Survey, Drs. F. L. Whitney and H. B. Stenzcl of The University of Texas, Prol. F. F. Smith of the A. \& M. College of Texas, and the laboratory of the Humble Oil and Refining Company at Houston, Texas, have assisted by identify. ing fossils. Mr. Frank Bryan, formerly of Waco, and Mr. A. Henry Bell of Waco have contributed information aboul the local geology.

'Thanks are also due to Messrs. C. L. Baker, S. S. Goldich, H. B. Stenzel, L. W. Stephenson, John Teagle, John ,T. Lonsdale, Mrs. Helen J. Plummer, and Miss Josephine Casey, as well as to several staff members of the Soil Conservation Service, for reviewing the manuscript and offering many constructive suggestions.

\section{GENERAL FEATURES OF TIIE FXPERIMENTAL WATERSHED}

\section{Climate: ano Acriculture}

The mean annual temperature at Waco is about $67^{\circ} \mathrm{F}$, and the mean annual rain. fall about 35 inches. Almost all the country for many miles around the experimental watershed; except for some areas near Brazos River, is used as farm land. Seventy-nine percent of the experimental area is cultivated, and most of the remainder is in pasture. Cotton, corn, oats, and sorghums are the principul crops grown; with livestock as a subordinate solirce of income. 


\section{Geology}

The Blacklands Experimental Watershed lies within the Black Prairie of Texas. The underlying rocks are marine sediments belonging to the Taylor group of the Upper Cretaceous, or Gulf series of the Cretaceous system, and consist of sandy marl, silty marl, chalk, highly calcareous marl, another chalk, and another highly calcareous marl, in ascending order. All dip east-southeastward toward the Gulf of Mexico al a gentle angle, which, however, is a little steeper than the general slope of the land surface. The successive formations therefore intersect the surface in par. allel bands, which cross the experimental area from southwest to northeast. On a few hilltops these Cretaceous strats are thinly covered, unconformably, by upland gravel deposits of probable Pliocene age, and along the principal drainageways by ancient and recent flood-plain deposits.

A large number of borings on the experimental watershed have shown that all the geologic materials are extensively oxidized to a depth of 20 to 30 feet below the ground surface, which has changed their color and appearance from that of the unaltered rock. This zone of oxidation is somewhat thicker on the hills than in the valleys. For several feet immediately below the soil the rock is ordinarily considerably decayed.

None of the geologic formations is very firmly consolidated, the chalk being the only one that at all approaches hard rock. In the zone of oxidation most of the other materials can be excavaled even without the use of a pick. With increasing depth the marls become harder and tougher and thus difficult to excavate.

The entire experimental area is mantled by deep soil, generally black, which originally supporled a vegetation consisting chiefly of tall grass, with trees and brush along the principal drainageways. Sínce the greater part of the watershed has been brought unider cultivation, considerable soil erosion has occurred, resulting here and there in the formation of bare spots and gullies, which together with the banks of the larger stream channels are the only places where outcrops of the underlying strata can be seen.

\section{TOFOGRAPHY ${ }^{5}$}

The topography of the experimental watershed is gently rolling, the elevation rariging from 464 to 592 feet above sea level. Long, smooth slopes are common, and drainageways arc rather widely spaced. Divides are commonly flat and poorly defined. Only 3 percent of the area has a slope grcater than 6 percent.

The lower of the two chalks, which crosses the experimental area as a narrow belt (Pl. I), is slightly more resistant to erosion than the other stratigraphic units. It forms a poorly developed low cuesta facing toward the northwest. This may be seen at the gap in the eastern ridge of Brushy Creek watershed just north of counly road 225 and also near the intersection of State highway No. 1.64 and road 223 , northeast of the project area. The hill on which the Government buildings stand (approximate Lat. $31^{\circ} 28^{\prime} 40^{\prime \prime}$, Long. $\left.96^{\circ} 53^{\prime} 10^{\prime}\right)$, as well as the corresponding hill northeast of it (approximate Lat. $31^{\circ} 29^{\prime} 10^{\prime \prime}$, Long. $\left.96^{\circ} 52^{\prime} 30^{\prime}\right)$, is capped by outliers of the chalk. For about 2 miles south-southwest from the Government buildings, the cuesta is emphasized by the rapid downcutting of the headwaters of Sandy and Big Sandy creeks (Pls. I and II) .

The greater resistance of the chalk also produces steeper slopes, a more irregular topography, and a grealor number of small watersheds in a given acreage than are commonly found in the remainder of the experimental area. The formation of numerous small drainages is probably aided by the ground-water seeps which occur along the outcrop of the base of the chalk. .

\section{Drainage}

Brushy Creek flows in a general south. easterly direction across the Cretaceous strata, which suggests that it is one of the older consequent streams of the Coastal Plain. ${ }^{\circ}$ Its tributarics, however, tend to

${ }^{5} A$ toriographic map on a scale of 1 inch equals 400 feet and a comtour intrrval of 2 feet sppears in Hydrologic Bullirtin 5 (Bairh, Ialutitzen, et al., I942).

FIt is recogrized that a Tertiary or early Quatoragry gravel plain, of which the rplund gravels called Uvalde in this report are remasnty, most have burit:d most of the original constal-plain topography. There is not enough evidence to show whether Brusby Cress originuted on this gravel plain or whether it rcorcravated an esrlier valley in the Crelaceous sediments. 
follow a northeasterly or southwesterly direction, following the strike of the rocks. This is especially true in the lower (southern) part of the experimental watershed, where dissection is further advanced. A trellis drainage pattern is therefore in process of development (Pls. I and II), which is rhomboidal rather than strictly rectangular.

In the course of this dissection of the elevated coastal plain, certain streams having a more direct route to Brazos River, or working on softer rocks, are able to cut down more rapidly and to capture parts of other stream systems having a gentler gradient. This appears to have occurred near the headwaters of Brushy Creek, which is a beheaded stream. A point on the boundary divide of the experimental watershed on road $221 \mathrm{~A}$ (Pl. I) is more than 25 feet lower than the present head. waters of Brushy Creek near road 219, about 3,000 feel away. It seems evident that this low point was formerly in the valley of Brushy Creek, and that the headwaters of a tributary of Trading Honse Creck, which flows into Tehuacana Creek and thence into Brazos River near Waco, have worked back from the north and have captured and reversed the flow of the former headwaters of Brushy Creek. The present source of the latier stream is in the valley of one of its former tributarics. Judging from the general topography of its present watershed, it seems unlikely that the drainage area which has been lost by Brushy Creek amounts to more than 3 or 4 square miles. The process is still going on, however, and the present headwaters of Brushy Creek are due to be captured in the geologically very near future. Comparatively slight artificial changes in the drainage of certain fields in the vicinity could accomplish this diversion al the present time.

Because of the impermeable nature of most of the underlying rocks in the experimental watershed and its vicinity, the ground waler is small in amount and is irregularly distributed. Consequently many of the drainageways flow only after rains; others receive contributions of ground water for a few months after a prolonged period of rainfall, but all of this may be lost by evaporation before il flows very far. Brushy Creek itself is normally dry during the late summer and fall. The large amount of easily eroded material carried from the higher slopes by the oc. casionally very intense rains builds flood plains along the lower courses of all but the smallest streams. Dcep channels, in places bordered by natural levees, are maintained by average rains and groundwater flow and meander through the flood plains on a very low gradient.

\section{ROCKS OF THE EXPERIMENTAL WATERSHED}

\section{Areal Distribution of the Geologic Units}

The areal distribution of the geologic units within the experimental watershed is shown in Plate $\mathrm{I}$, which also shows the location of auger holes and wells.

The boundary shown between the Pecan Gap lower chalk and the Wolfe City silty marl has been rather accurately determined over most of the experimental arèa through numerous exploratory borings, location of ground-water seeps, material excavated by crawfish, and similar indications. The other boundaries of the Crelaccous units are based on the evidence of oulcrops and borings but are quite arbitrary and generalized. The upper chalk at the southeast corner of the experimental area has been located chiefly by interpretation from holes 1000 and 1010 and from the outcrops on Brushy Crcek and its tributary.

,The upland gravel (Uvalde formation), the terrace alluvium, and the Recent alluvium are shown as patterns superimposed on the older formations. In outlining them the distribution of soil types, shown on the conservalion survey map in Hydrologic Bulletin 5 (Baird, Lauritzen, et al., 1942) has been of very great assistance. Because of the difficulty of identifying the alluvial marl and its irregular distribution, the boundaries shown for the lerrace alluvium are prohably the least accurale of the geologieal boundaries shown in Plate I, and are largely the result of interpretation, especially on the spurs between the tribu. taries of Brushy Creek. The terrace alluvium is not shown where it is overlain by the Recent alluvium. 
TAELE 1

GEOLOCIC UNITS AT THE BLACKLANDS EXPERIMENTAL WATERSHED, TEXAS

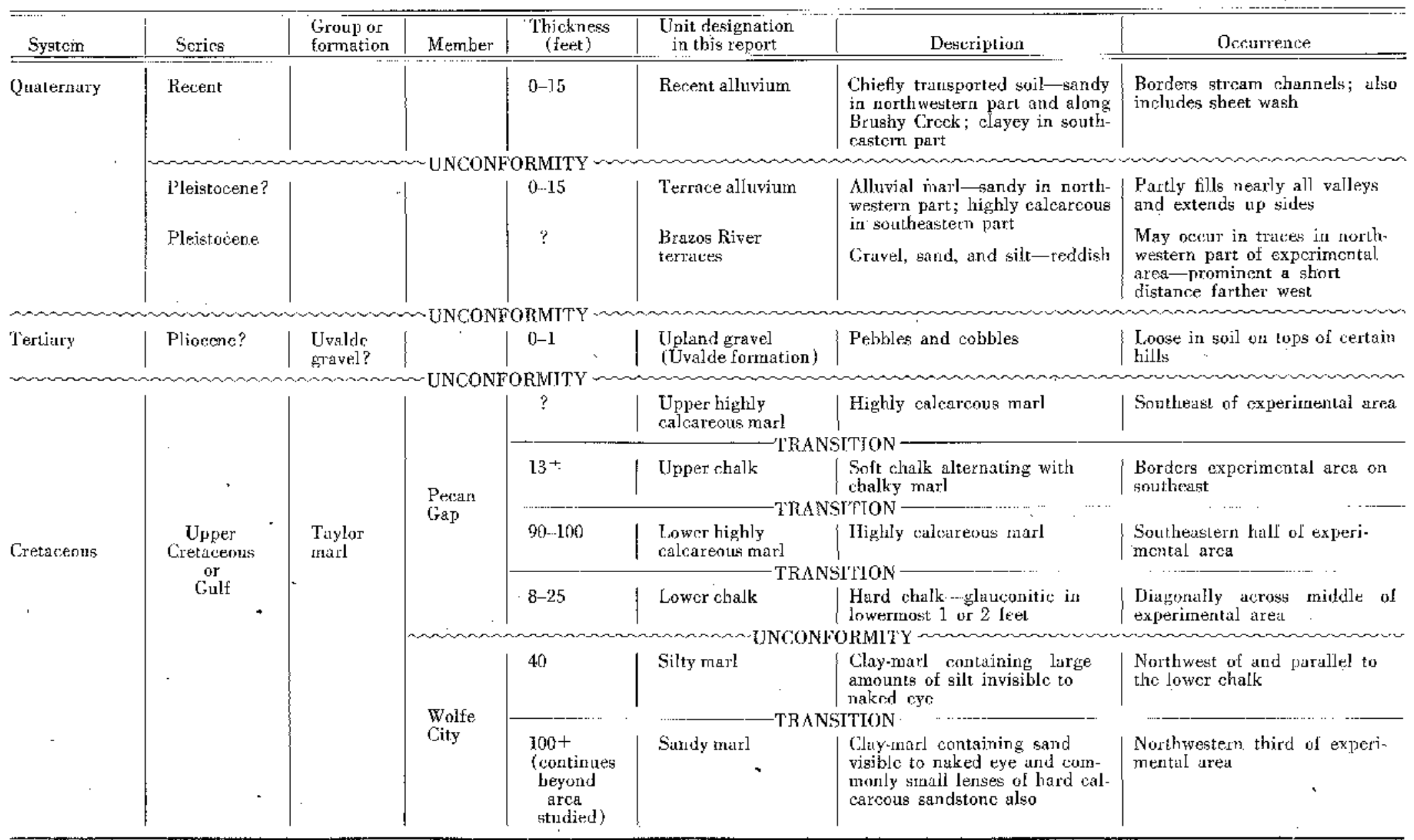




\section{Wol.e City Member of TAYLOR MarL}

Divisions.-The lowest strala cropping out in the experimental watershed are sandy and silty marls. Their band of out crop conlitins approximately the northwestern half of the project arca and much addilional territory farther northwest; its exact limit in this direction was not in. vestigated. They underlie the entire project area at depths increasing loward the southcast.

These marls may be arbitrarily divided inio two parts, the sandy marl and the silty marl. The sandy marl contains visible sand and usually also numerous lenses of hard calcareous sandstonc. In the overlying silty marl the abundanl silt particles are too small to be visible to the unaided eye. In this region these divisions grade into each other vertically but apparently not laterally, and hence they are convenient stratigraphic distinctions.

Sandy marl.-The sandy marl may be seen in the road ditch on county road $221 \mathrm{~A}$ northeast of well 850 (Pl. I), on road 229 just cast of its easterly inlersection with road 228 , and on road 233 west of well 352 and also near well 1012 . It also crops out in a large gully at about Lat. $31^{\circ} 30^{\prime} 35^{\prime \prime}$, Long. $96^{\circ} 53^{\prime} 35^{\prime \prime}$. Better outerops may be seen northwest of the project area on the headwaters of Maness Creek near the road crossing a $\mathrm{a}$ upproximate Lat. $31^{\circ} 31^{\prime} 00^{\prime}$, Long. $96^{\circ} 55^{\prime} 30^{\prime \prime}$ (loc. 27, Pl. II). On Brushy Creek there is a small cxposure at the bend at approximate Lat. $31^{\circ} 29^{\prime} 25^{\prime \prime}$, Long. $96^{\circ} 52^{\prime} 50^{\prime \prime}$. Transitional marl in which the sand is barely visible occurs where the creek has cut through a neck at approximate Lat. $31^{\circ} 29^{\prime} 20^{\prime \prime}$, Long. $96^{\circ} 52^{\prime} 30^{\prime \prime}$.

Borings have shown that the unoxidized marl of these strata is b]uish gray in the coarser parts to bluish black in the finer layers, but near the surface it is usually a rusly ycllowish-brown color, in places mottled with gray in tho less completely oxidized portions. Large exposures usually show imperfecl stratificalion, due at least in part to poorly developed bedding fractures.

Sand or silt is abundant throughout the marl, and its coarseness increases downward, although probably not with absoIute regularity, from the top of the silty marl.
As the sand becomes coarser it tends to segregate in distinct laminae and in gray lenses and pockets enclosed in darker material which is richer in silt and clay. As these lenses increase in size and in coarseness of texture, many of them are found comented into hard sandstone by finegrained crystalline calcite. There seems to he no definite arrangement of these sandstone lenses, except that their long axes are parallel to the bedding of the marl. They range from about half an inch to about 2 feet across, and they are not continuous at any onc horizon except for very short distances. The cementation appoars unrelated to any weathering process, for the sandstone lenses are found in both the oxidized and unoxidized marl and have been recovered in borings from depths as great as 200 feet.

In thin section the marls of these strata are composed of a ground-mass of very fine silt, carbonste, and clay, ranging in texture from grains about $0.017 \mathrm{~mm}$ in diameter down to cloudy material beyond the resolving power of the microscope. Thickly scaltered through the ground-mass are grains of coarsor sill and sand, almost all sharply angular. In the sandy marl beds there is a noticeable hiatus between the size ranges of the admixed silt and sand and of the ground-mass. A few microscopic fossils are present.

Most of the sand and coarser silt grains are composed of quartz, accompanicd by considerable cherl and some feldspar, part of which is plagioclase. Micas are rare, although decayed biotite and chIorile are occasionally seen. Heavy minerals include a considerable amount of marcasite in spherical aggregates, especially in the unoxidized material, and lesser amounts of ilmenite, zircon, and colorless garnet. A little tourmaline and rutile are also present. The zircon is of two distinct types, wellpreserved zirconoids and much-rounded grains.

All the sandy marl found on the experimental watershed, except a fow of the uncemented very sandy lcnses, contains enough carbonate to effervesce with dilute hydrochloric acid. Judging from the analyses shown in table 3 , its calcium carbonate content ranges from 5 to 15 percent.

Mugascopic fossils are rather scarce in the sandy and silty marts, but occasional 
shell fragments occur of which Inoceramus is the only recognizable genus.

Silty marl.-Typical silty marl crops out on the lower reaches of the stream flowing from watershed $Y$ and at several sharp bends of Brushy Creek just above its junction with this stream. It is also ex. posed in. gullies at a property corner at approximate Lat. $31^{\circ} 29^{\prime} 17^{\prime \prime}$, Long. $96^{\circ} 52^{\prime}$ $45^{\prime \prime}$, and on road 238 just south of well 249 .

The differences between the silty and sandy marls are of degree rather than of kind. In appearance the silty marl is similar to the sandy marl in the corresponding state of oxidation, except that it is more uniform because of the absence of sandy lenses and laminae. At some places the unoxidized silty marl has a greenish cast. Stratification is less noticeable than in the sandy marl but is more noticeable than in the highly calcareous marls of the Pecan Gap member.

Although the silt abundant throughout this marl is invisible to the unaided eye, it can readily bo felt between the teeth, and it is easily seen under the microscope in thin section. The difference in size between the admixed silt and the ground-mass is much less marked than in the sandy marl.

The silty marl is richer in carbonate and in clay than the sandy marl and consequently poorer in silica (tables 3 and 4). $A_{s}$ in the sandy marl, megascopic fossils are not common, although microscopic fossils are generally present.

The silty marl overlies the sandy marl and is in turn overlain by a stratum of chalk which, as described below, is regarded as belonging to the Pecan Gap member of the Taylor marl. The silty and sandy marls must therefore be correlated with the Wolfe City member of the Taylor. Although the exact southern limit of this member probably cannot be defined, on the geologic map of Texas (Darton et al., 1937) the strata immediately below the Pecan Gap chalk have been mapped as Wolfe City as far south as Bell County. Dane and Stephenson (1928, p. 50) state "...... the 350-foot soction included in the Wolfe City sand in southern Hill and southwestern Navarro counties becomes decreasingly sandy southward through Limestone and eastern McLennan counties:- Characteristically it is a bedded sandy marl with regular even beds of either pure or slightly sandy marl ranging from $1 / 2$ to 1 inch thick, with intervening thinner sheets and vermicular pockets of soft clean sand. A few lenses of hard calcareous sandstone may be as much as 4 inches thick." This fairly well describes the sandy marl beds of the experimental watershed. They say also (p. 54), "Toward the south. west (from Prairie Hill) the sandy constituent diminishes and in the vicinity of Mart and Marlin the beds immediately below the chalk are pure marl without perceptible sand content." These are evidently the silty marl beds found on the experi. mental area.

As calculated from the strike and dip of the chalk-silty marl contact, discussed below, the total thickness of the strata below the chalk in the experimental watershed is about 150 feet. On the basis of the samples obtained from several borings; the upper. most 40 feet of this has been assigned to the silty marl. This thickness was used to calculate the width of the band of outcrop shown in Plate $I$, and only slight adjustments were necded to make this agree with all the known outcrops.

\section{Pecan Gap Member of Taylor Mart.}

Lower chalk.-A narrow band of chalk extends irregularly across the middle of the experimental watershed from southwest to northeast, with outliers capping certain isolated hills (Pl, I). The overlyjng shallow soil has been severely eroded where it has been cultivated on steep slopes, and the white subsoil and decayed chalk appear in the fields. Still more accelerated erosion at a few places has exposed hard ledges, as in the farmyard at locality 5, Plate II (near well 91, Pl. 1), Apart from such places outcrops are not common, as the chalk is ordinarily hard enough to resist gullying. Outcrops may be seen, however, in a gully at approximate Lat. $31^{\circ} 27^{\prime} 35^{\prime \prime}$, Long. $96^{\circ} 53^{\prime} 35^{\prime \prime}$, in the right bank of the stream draining watershed $\mathrm{Y}$ near spring 28, on Brushy Creek from about 1,000 feet below gaging station $\mathrm{G}$ to spring well 26 , and in a gully at spring 14, approximate Lat. $31^{\circ} 29^{\prime} 30^{\prime \prime}$, Long. $96^{\circ} 52^{\prime} 00^{\prime \prime}$.

Below the zone of oxidation chalk from borings is bluish gray, somewhat lighter in color than the silty marl beneath it. In the oxidized zone where covered by soil 
it is usually a pale yellowish-brown or cream color. Where exposed directly to the elements it becomes white. At most places the chalk shows no stratification or Iamination, but in outcrops of the basal portion a suggestion of heavy-bcdded structure develops on weathering.

The chalk is not so hard as, and is more easily weathered than, the typical chalk of the Austin formation of central Texas. Nevertheless, in both oxidized and un. oxidized state it is ordinarily too hard to be grooved by the fingernail, which distinguishes it from the overlying highly calcareous marl. Exposure seems to increase its hardness to some extent. Although where covered by a thin layer of soil it disintegrates rather readily, cutbanks and exposed blocks retain their shape for several years. The chalk is more brittle than any of the other rocks in the project area, and in the zone of weathering it' is extensively fractured; a condition of great importance to the distribution of the ground water. . It does not, however, possess the fincly spaced conchoidal fracture characteristic of the highly calcareous marl.

Most of the lower chalk is too tine to be resolved by the naked eye or by a hand lens and does not contain sand or silt noliceable between the teeth. The apparent grittiness at first felt on chewing a'specimen is due to the calcareous fossils and disappears as they gradually are crushed or dissolve. Near the base of the chalk, however, there is in many places a zone of: coarser texture, extremely rich in foraminifera, some of which are large enough to be visible. This part of the chalk also contains a little coarse silt or sand, although not so much as in the silty marl below. In its lowermost 1 or 2 feet the chalk also contains numerous rounded grains of glauconite, which are dark green in the unoxidized material but appear merely as rusty spots in the weathered rock.

Thin sections taken from the lower partof the chalk above the glauconitic zone show it to contain much the same materials. as the underlying silty marl but in relatively very different amounts. The groundmass is made up of particles ranging from about $0.006 \mathrm{~mm}$ in diameter down to beyond the resolving power of the microscope, in a mass of slill finer, cloudy material. The particles are nearly all carbonate, as much of the cloudy material also appears to be. Thickly scattered throughout the ground-mass are calcareous fossils, mostly foraminifera, and fossil fragments, of an average size of from 0.04 to $0.09 \mathrm{~mm}$. An appreciable number of angular silt grains of about the same size range are also present but less abundantly than in the underlying silty marl. The unoxidized chalk contains also numerous marcasite balls and irregular black spots which appear to be organic matter.

All the numerous chalk specimens tested effervesce vigorously with cold dilute hydrochloric acid. The chemical analyscs in table 3 show a carbonate content for the chalk of between 70 and 80 percent, and rough analyses indicale that it may reach 90 percent in some specimens. On solution in hydrochloric acid the unoxidized chalk leaves a scummy, residue of organic material along with the insoluble clay and silt.

Megascopic fossils occur occasionally throughout the chalk and are most numerous near its base. Shells of Exogyra pond. eroso are found frequently, and of Durania austinensis rarely, in the soil throughout the belt of outcrop. The following fossils, from just above the base of the chalk at tho site of the Government buildings, have been identified by Dr. F. L. Whitney of The Universily of Texas:

Inoceramus crippsi var. barabini Meek (?)

Baculites sp., probably asper

Eutrcphoceras sp.

Undetermined aminonites

The Inoceramus and Baculites were found also just above the base of the chalk at hole 1020 on Brazos River (Pl. Il) and at other localities.

Numerous borings throughout the experimental area and a few in the adjacent region, as. well as outcrops on Big Sandy Creek described below, have shown that the base of the chalk is a sharp contact with the underlying silty marl. Its upper limit is much less definite, and it passes by imperceptible gradations into the overlying highly calcareous marl through a zone of material which is intermediate betwcen the two. Where the full thickness of the chalk is not represented, as where it is overlain by soil or by alluvial marl, the hard rock may be much more sharply de- 
fined. Near the belt of outcrop the fuill thickness of the hard chalk is between 8 and 14 feet. Down the dip it appeurs to thicken somewhat, and in hole 1010 the thickness was recorded as 22.5 feet.

From its stratigraphic position and its sinilarity to the chalks described by Dane and Stephenson (1928), Ellisor and Teagle (1934), and Rouse (1944), there seems little doube that this chalk belongs to the Pecan Gap member of the Taylor marl. Its relation to the chalk outerops described by thesc authors is discussed in a following section.

Lower highly calcareous marl.-Tho southeastcrn half of the experimental area is immediately underlain by a highly calcareous marl, into which the chalk grades imperceptibly, as above described. This material is exposed in many outcrops along Brushy Creek from the vicinity of spring well 26 (approximate Lat. $31^{\circ} 28^{\prime} 52^{\prime \prime}$, Long. $\left.96^{\circ} 51^{\prime} 50^{\prime \prime}\right)$ to below gaging station J. It also appears in a gully at approximate Lat. $31^{\circ} 28^{\prime} 28^{\prime \prime}$, Long. $96^{\circ} 51^{\prime} 55^{\prime \prime}$, and in gullies along road 337 both east and west of Brushy Creek:

In appearance and properties the highly calcareous marl is the most uniform of all the rocks on the project area. It shows no stratification or lamination, either in outcrops or in small pieccs. Where recovered by borings from below the zone of oxidation, this marl has the bluish-gray appearance of the underlying chalk, from which it cannot readily be distinguished except by its lesser hardness. Beneath the soil in the zone of oxidation the marl usually acquires a yellowish-white to tan color, somewhat yellower than the chalk, but where exposed directly al the surface it becomes white like the chalk. The most outstanding difference results from prolonged exposure to the elements. The chalk remains hard for at least several years, but the marl, after a few alternate wettings and dryings, shrinks and checks through the formation of a multitude of conchoidal fractures, probably because of a change in volume with change in moisture content. 'This permits an outerop of marl to slump rather easily and crumble away. "Thus the highly calcareous marl becomes severely gullied by the concentration of run-off water much more easily than the chalk. This is also true, although to a somewhat lesser degree, of the silty and sandy marls below the chalk.

Thin sections show that, like the chalk, the highly calcareous marl consists of a ground-mass rich in carbonate, through which arc scattered numerous tiny calcareous fossils, which nevertheless are less abundant than in the chalk. Silt grains are rare and consist of the same minerals as in the other strata studied. No silt can be delected on chewing the average specimen. $A s$ in the chalk, the ground-mass consists of a multitude of grains less than $0.01 \mathrm{~mm}$ in diameter and embedded in a cloudy, unresolvable material. Many of the grains are crystalline calcite or dolomite, some being perfect rhombs, but many others are not carbonale and apparently are very fine detrital material. Like the chalk, in thin section the unoxidized marl shows marcasite aggregates and organic matter.

The partial chemical analyses in table 3 show that the highly calcareous marl contains approximately 50 percent calcium carbonate. Table 4 shows that its acidinsoluble portion contains more clay than docs the residue from any of the other geologic materials under consideration.

The highly calcareous marl contains fewer megascopic fossils than the chalk but more than either the sandy or the silly marl. Occusional unidentifiable shell frag. ments and impressions occur, and impressions of Inoceramus were noted.

The highly calcareous marl is transitional into hard chalk below and into soft chalk or chalky marl above. Consequently its upper and lower boundaries must be arbitrarily established. In hole 1010, where both upper and lower chalks were penelrated, the thickness of the marl. be. tween them was regarded as 94 feet.

In the surrounding region chalk outcrops corresponding to both the upper and the lower chalks of the experimental area have been correlated with the Pecan Gap member of the Taylor group. This term must therefore include the highly calcareous marl between them, and probably also much of the similar marl above the upper chalk.

Upper chalk.-In holes 1000 and 1010 , about half a mile southeast of the Iower end of the main experimental walershed (Pl. J), thin layers of a bluish-gray $50 \mathrm{ft}$ chalk or chalky marl were found, grading 
into marl above and below. Similar solt chalk or hard marl, white because more oxidized, was found on the right hank of Brushy Creek at approximale Lat. $31^{\circ} 27^{\prime}$ $47^{\prime \prime}$, Long. $96^{\circ} 50^{\prime} 50^{\prime \prime}$, and on the tributary stream about 900 feet west of this point; just above well 156.

In appearance this chalk cannot be dis. tinguished from the highly calcarcous marl jusl described, except for its slightly greater hardness and accompanying increased brittleness. It is somewhat more resistant to weathering, but the difference is not greal enough to give topographic expression to its belt of outcrop.

A thin section of the chalk from hole 1000 shows it to be very similar in texture and structure to the lower chalk and to the highly calcareous marl. In abundance of microscopic fossils it lies between the two. It differs from the lower chalk in its smaller content of the larger silt grains, which are even less abundant than in the highly calcareous marI.

The chemical analyses in table 3 show that this upper chalk is very similar to the lower in carbonate and silica content.

No megascopic fossils have been found directly in the upper chalk at the borings and outcrops just described, hut outcrops of highly calcareous marl in the immediate vicinity, and not far distant stratigraphically, have yielded undetermined species of Inoceramus, Pecten, and Ostrea, and also Pycrodonte vesicularis. Durania austinensis has been found loose in the soil. Diploschiza cretacea minor has been found in marl outcrops on Brushy and Little Brushy crecks just soulheast of, and stratigraphically a little above, this chalk.

In hole 1010 the upper chalk occupied a zono about 13 fect thick; in hole 1000 it was not completely penetraled. Observations at these holes and at the outcrops indicate that within this zone the chalkier layers alternate with softer, marlier layers, but the changes are gradational and not sharp. For this reason any estimate of the thickness must be rather arbitrary.

Upper highly calcareous marl.-The upper chalk is transitional upward into another highly calcareous marl, similar in all its properties to the lower highly cal. careous marl already described and indis. tinguishable from the latter by any lithologic crileria.
The upper highly calcareous marl crops out along Brushy and Little Brushy creeks. just south of road 339 . Its thickness and. extent were not investigated, but judging from the few oulcrops visited, its band of outcrop has a width of about 2 miles, bcyond which, loward the southeast, the marl gradually becomes appreciably sandy.

It is not known how much of this upper highly calcareous marl should be included in the Peran Gap member of the Taylor group. In part it may correspond to what has been regarded by some geologists as a southern extension of the Marlbrook marl of Arkansas.

\section{Ariduviat. anj, Colduvial. Deposits}

Classification.-Over much of the $\mathrm{ex}$ perimental area and throughout the sur. rounding region, especially toward the west and southwest, more or less alluvial material is present. Its former almost continuous extent is attested by the fact that a litlle sand and a few pebbles are every. where found in the soil known as the IIouston hlack clay (Baird, Lauritzen, et al., 1942, p. 35), even where this soil rests upon and has apparently been formed exclusively from sand-free highly calcareous marl. The present alluvial deposits vary greatly in composition, thickness, and distribution, but in general they consist of three principal types:

(a) Definite deposits of sullicient thickness to mask the underlying strata nearly completcly and to govern the development of the topography and the soils.

(b) Erosion remnants consisting only of the coarser constituents of former alluvial deposits which have been almost completely removed.

(c) Recent colluvial and alluviai material, which consists chielly of soil and much of which is still being actively shifted. Because of the difficulty of deciding where colluvium ends and alluvium begins, all such material is regarded as alluvium for the present purpose.

As geologic units the alluvial deposits may be classified as follows, beginning with the oldest:

\footnotetext{
Upland gravel (Uvalde formation)

Terraces of Brazos River

T'errace alluvium. along Brushy Creek

Recent alluvium
} 
Upland gravel (Uvalde formation).-Coarse gravel and cobbles are abundant in the soil on the tops of certain of the higher hills and ridges on the western and southwestern borders of the project area, as shown in Plate I, and may be seen near wolls 114 and 670. They are even more abundant in a field about I mile westsouthwest from Trinity Church (loc. 28, Pl. II). Such soils have been mapped as Houston black clay, gravelly phase (Baird, Lauritzen, et al, 1942, p. 35.)

These deposits never amount to definite gravel beds, and in some places they consist merely of accasional cobbles. The cobbles and pebbles are often found far down the adjacent hillsides (as for example east of well 670) and along the stream channels, but thrir concentration is greatest on the tops of the divides.

Nearly all the pebbles and cobbles in these deposits are well rounded, and a few show evidence of wind faceting. They range up to about 4 inches in diameter, but sizes below "pea gravel" are much less abundant. They consist largely of gray chert and flint, nearly all of which is much devitrified on the outside and in some cases throughout. Quartzites and quartzitic sandstones are also abundant, many of them reddish or purplish. Minor conslituents include vein quarlz, both milky and color-: less, red jasper, silicified wood, decayed gneiss, decayed hornblende schist, and similar metamorphic and igneous' rocks which must have come from far distant sources. Limestones are entirely absent, although some of the pebbles show calcium carbonate coatings, which seem now to be in process of solution rather than of deposition.

The devitrification and decay shown by most of the pebbles and cobbles are noteworthy. Only those composed entirely of crystalline quartz are fresh in appearance.

It seems probable that these gravels represent erosion remnants of the earliest fluviatile deposits of the region. No fossils. have been found in them, except loose shells of Exogyra ponderosa obviously derived from the underlying chalk or marl.

Similar upland interstream gravels are more prominent farther south in central Texas. Although because of the general absence of fossils no exact correlation of the different occurrences has been possible, all of them have been grouped by most writers with the Uvalde formation (formerly called Reynosa by some geologists) . A general description of the deposits and a history of the two names is given by Plummer (1933, pp. 777-779). Hill (1901, pp. 346-349) describes gravel "of the Uvalde type" in Bell County, and Deussen (1924, p. 106 and pl. 8) maps occurrences as far north as southern McLennan Counity. Sayre (1936, pp. 65-67) describes the Uvalde gravel in Uvalde County as containing limestone pebbles and some silt, both of which are absent in the gravels of the experimental watershed. However, Deussen points out that the composition of the deposits varies in the different major crainage basins, and Stenzel (1938, pp. 161-169) notes the total absence of limestone pebbles in the upland (Uvaldc) gravels of Ieen County.

All the upland interstream gravels, inlcluding those on the experimental watershed, are topographically higher, more croded, and more weathered than any of the terraces which can be related to the present major streams. Early Pleistocene fossils have been found in some of these terraces, and therefore the upland gravels are probably not younger than late Pliocene or oldest Pleistocene (Plummer, 1933, p. 779). As the upland gravels represent the.channels or flood plains of the strcams at the time of their deposition, all the present topography of this region must have developed since Pliocene time.

Terraces of the Brazos River,-About 1 mile west of the southwestern corner of the project area, and on a generally lower levcl, much of the land surface is blanketed by a fresh-water dcposit containing much reddish gravel and considerable sand. Similar material covers the ridge on which the village of Riesel stands and occurs also on the next ridge to the north and at the intersection of State highways No. 6 and 164 (Pl. II). It is also found extensively in northern Falls County in the region east of Perry.

In these deposits, in contrast to the up. land gravels assigned to the Uvalde formation, the finer sizes of pebbles are much more abundant, although cobbles up to 4 inchcs in diameter are occasionally found: The devitrified flints and cherts of the upland gravel are almost entirely $a b$ - 
sent, but brown and black flints, only slightly decayed, are very common, as is also milky quartz. Reddish quartzites are also abundant and give a slightly reddish cast to most of the mualerial.

These deposits are sufficiently thick and extensive to change matcrially the character of the soils and natural vegetation. Where not cultivated they support a growth of post-oak trees. 'They are found capping the lower hills on both sides of Brazos River in this region and may represent the oldest of the Pleistocene terraces of the river, which are discussed by Deussen (1924, pp. 114-115 and pl. 33) and Hill (I.901, pp. 352-360).

A thin sprinkling of similar small reddish pebbles is found on the surface of the soil at many places along the western ridge of the main experimental watershed between roads 225 and $221 \mathrm{~A}$ (PI. I). This deposit lics at a higher elevation than the deposits mentioned above and may be the last remnant of a still older terrace. There is a strond suggestion that it may have contributed to the development of the Crockelt soils in this vicinily.

In Falls County northwest of Marlin, below the level of the reddish gravel terrace, there is a distinctly different terrace consisting principally of red silt with some clay and characterized by concretions and segregations of white calcium carbonate, several inches in diameter, at shallow depths. This deposit is sufficiently thick and continuous to blanket completely most of the underlying rocks except where it is deeply dissected hy gullies or streams. It does not occur on the cxperimental water. shed, but it overlies the type exposure of the Marlin chalk just south of Marlin and adds greatly to the difficulty of tracing the various Cretaceous strata in that vicinity.

Terrace alluvium along Brushy Creek and adjacent streams.-At many places in the experimental arca and in the surrounding territory there are extensive alluvial deposits of a nature quite different from the dominantly gravelly or sandy deposits above described. Most of them consist of weathered rmarl very similar to that formed by decay of the residual marl in their irnmediate vicinity but containing various amounts of coarse sand and gravel. They occur not only beneath the present flood plains of the principal streams, such as
Brushy, Little Brushy, Big, and Trading House creeks, but well up the valley sides and in the valleys of most of the minor tributaries nearly, but not quite, as far as the interstream divides, where they may merge with the colluvial wash from the upland gravel and other deposits capping the hills. In conlrast to the upland gravel, however, their position is cverywhere clearly related to the main features of the present topography and drainage systems.

Good exposures of these alluvial marls may be seen at marry outcrops on Brushy Creck, southward from spring well 26 (Pl. I), at some of which their relation to the residual marl is well shown; also in the gullies on the south side of road 337 about one-quarter mile west of Brushy Creek. A type made up almost exclusively of calcareous materials is exposed in the gully at approximate Lat. $31^{\circ} 28^{\prime} 35^{\prime \prime}$, Long. $96^{\circ} 51^{\prime} 50^{\prime \prime}$, and in the gullies entering Brushy Creek from the east bctwecn gaging station $G$ and road 233 . The banks of the northernmost of these gullics show the change in the character of the alluvial ma. terials as contributions were received from the headwaters of its stream or from the main creek. A very sandy type of alluvial marl, found also on Brushy Creek water. shed, may be seen along the "County Line Road" about 6 miles north-norlhwest of Mart, just north of the crossing of Trading House Creck.

On the east side of Brushy Creek the entire gently sloping plain, which is about half a mile wide at road 233 , is built of alluvial marl.

In contrast to the upland gravel and the Brazos River terrace deposits, the alluvial marls of the present discussion are cverywhere characterized by the local, often very local, origir of their constituent materials. In consequence two distinct types of this alluviurn occur on the experimental watershed. A sandy alluvial marl, derived chicfly from the sandy marls of the Wolfe City member, is found in the northwestern part of the area, and a highly calcareous alluvial marl, derived from the Pecan Gap meruber, occurs in tributary valleys of the southeastem part. For a short distance south of the Pecan Gap-Wolfe City contact, the alluvial marl along Brushy Creek is somewhat intermediato between these types, bul it soon becomes dominanlly 
calcareous as more and more tributaries enter from Pecan Gap terrilory. Large pebbles are common in the highly calcareous type and small ones in the sandy type, which suggests that no upland gravel remnants other than those now known have been present in the watershed since before the period of deposition of the alluvial marl.

Because of this local origin, at most places the alluvial marl is very similar in color and appoarance to the underlying residual marl, and unless the former con. tains considerable gravel and sand it is not easily distinguished. The mere presence of a little gravel or sand is not an infallible criterion, because in drier sea. sons wide cracks form in the soil and often extend far down into the underlying parent material, permitting sand or small pebbles to be blown or washed into any of the residual formations. In outcrops and excavations, however, these filled cracks can usually be detected. Also, where true alluvial marl is present a fine line of demarcation is often visible between it and the underlying residual material. Pebbles, especially the larger ones, are frequently more numerous just above this line. Further. more, however closely the alluvial marl may resemblc the underlying material in texture and composition, its structure in. dicates that it is made up of a great many small lumps that have previously been separated, as shown by numerous shiny surfaces, which contrast with the duller appearance of the characteristic fracture surfaces of the residual marl. Perhaps because of this structure, gullies start and enlarge much more readily in the alluvial marl. However, all these distinctions require a large and clean exposure, and in borings, unless undisturbed material or large pebbles are recovered, the distinction is quite difficult and is often uncertain.

In thin section the distinction is somewhat easier, since most specimens of alluvial marl contain material coarser than any sand found in the residual marls, even those of the Wolfe City member. Nost of these coarser grains in the alluvial marl are well rounded, whereas most of the sand grains in the Wolfe City are sharply angular. The mechanical analyses (table 4) illustrate the much wider range of sand sizes in the alluvial marl. "The ground- mass of very fine silt, carbonate, and clay, however, appoars much the same in both rosidual and alluvial marls. As seen in table 3 , the admixturc of material from non-Cretaceous sources may not cause a difference in chemical composilion any greater than the variations within the Cre. taceous formations themselves.

No lossils have been found in the allu. vial marl which appear to be contemporancous with its deposition. It contains numerous shells eroded from the Cretaceous formations.

From observations at the numerous bor. ings and exposures where the alluvial marl was encountered, it seems unlikely that it is more than I5 feet thick at any place on the experimental watershed. It averages somewhat more than 10 feet thick on the old flood plain of Brushy Creek and between 5 and 10 feet thick in the tributary valleys. These figures include the soil developed from the alluvial marl. Farther up the valley sides it is generally thinner and in many places absent.

Because of scarcity of exposures, irregular distribution, and uncertain identification in borings, the exact extent of the alluvial marl was very difficult to map. Enough evidence was obtained, however, to show that the greater part of it forms a terrace or terraces along Brushy Creek and its tributaries. It is therefore referred to in this report as the terrace alluvium. The topography suggests that there may be at least two terraces, the one forming the ancient flood plain along Brushy Creek already referred to and the other lying at higher levels on the steeper valley sides and now largely eroded. This seems probable, bul no recognizable distinction between materials from the two locations was found.

The terrace alluvium is unquestionably younger than the upland gravel remnants, whose materials it incorporates. It is likewise older than the Recent alluvium which overlies it and its soil at many places along Brushy Creek. In similar topographic situations the depth and degree of develop. ment of the soil on the terrace alluvium is much more comparable to that of the soil on the residual marls than to that on the Recent alluvium. These considerations suggest that the terrace alluvium is of Pleistocene age, and that it corresponds to 
one or more of the lerraces of Brazos River, most of which were formed during that epoch.

It is difficult to imagine that the large quantity of material represented by the terrace alluvium could have been eroded and transported by a stream no larger than the present Brushy Creek. NevertheIess, even allowing for the capturc of its headwaters by the Tehuacana drainage system, there is no indication that Brushy Creek ever drained an area much larger than it now drains. It is therefore necessary to assume a much greater volume of stream flow than at present and consequently a much heavier rainfall. These conditions are not inconceivable during the Pleislocene, when great differences in temperature probably existed between the atrrosphere over different portions of the earth.

Stenzel (1938, p. 169) noted the remarkable development of terraces along the smaller drainage lines of Leon County. From a study of the meander scars and alluvial fans along the valley of Navasota River, he concluded ( $p p$. 181-184) that that stream also formerly had a much. greater volume than at present. He states that the phenomenon is not local but regional. ${ }^{7}$

If the terrace alluvium was deposited by running water it must have resulted from very turbulent run-off. The very local origin of the materials, the heterogeneous mixture of pebbles, lumps of undecayed marl, sand, and clay, and the general absence of stratification can be accounled for by flash floods, rapid erosion, brief transportation, and quick deposition. But the most surprising feature of this alluvial marl is the total absence of anything resembling soil in its composition. The soil now overlying it is a residual soil, formed in place from the terrace alluvium as parent material.

Even if it is assumed that the region was a desert with only intermittent heavy rainfall, some kind of soil should have been present at the time of deposition of the alluvial marl, especially since the parent materials were not quartz and resistant silicates but easily weathered clay and lime

\footnotetext{
TThr grenent suthors wexe ugacquainted with Dr. Sturixel's work st the tims they reached their conclusions regardipy Brushy Creek.
}

mud. This should have been true even if the climate were cold, provided that it was not actually glacial. A possible explanation is that during this time the blacklands had heen completely denuded of their soil cover, and that the forces of erosion were acting directly on the decayed and even on the sound residual marl, together with the remnants of the upland gravel. This implies an intensity of erosion far bcyond anything taking place under even the most careless agricultural methods of the present day. The terrace deposits may therefore be the rccord of only the later stages of this erosion, the original soil having been washed completely out of the country. This would also mean that all the present soil of the entire watershed has been formed since the Pleistocene. Although drastic, none of these implications is inconsistent with the great changes in climate and base level which must have occurred during Pleistocene time.

An alternative explanation was first suggested to the writer (Blank) by C. L. Baker (personal communication, May 8, 1942). The heterogeneous nature of the alluvial marl, and the absence of stratification within it, might indicate an origin by soil creep or mass wastage from the sides of the valIeys, rather than by deposilion by turbulent streams having greater volume than they now possess. This might also explain the very local origin of ils constituent materials. The concentration of pebbles found here and there at the base of the alluvial marl might correspond to the stone lines observed by Sharpe (1938, pp. 24-25; in Ireland, Sharpe, and Eargle, 1939, pp. 22-23) at the base of the creeping mantle in South Carolina, rather than to the "basal conglomerate" of a sedimentary deposit.

Mass wasting is now going on along the steep banks of Brushy Creek and some of its tributary gullies, but at first thought it would seem that the slopes of the buried Brushy Creek valley in the residual marl, as revealed by borings, are too gentle to permit any large part of the terrace alluvium having been formed in this way. Nevertheless, cerlain studies of the soils on the watershed suggest that even on these gentle slopes soil creep may be appreciable at the present time. Both the soil and the underlying marl expand and contract 
considerably with clunges in moisture content, and this results in movement of at least the surface layers. When the soil becomes thoroughly saturated after heavy rains it acquires properties ressmbling those of a viscous liquid, and the alluvial marl can be brought to the same condition artificially without much difficuliy. It is possible, therefore, that the entire mantle of soil and underlying marl, down to the depth to which moislure changes occur, may for a long time have been slowly creeping and flowing down the slopes and accumulating in the valleys without any radical dislocation of the normal sequence of decayed marl and its overlying soil horizons taking place during the process. As this material accumulated in the valleys the streams would cul gullies and channols in it and, overtopping these trenches during floods, might level and re-work the valley fill to some extent. Bul such stream action may actually be the miror factor in the origin of the geologic formation herein called the terrace alluvium.

Recent alluvitum,-Recent alluvial deposits, which are still accurnulating, occur along most of the streams of the region, from the smallest to the largest, including Brazos River. Along Brushy Creek and its larger tributaries the Recent allivium occupies a narrow belt along both sides of the channel, which conslitutes the area overflowed by the average high water. Deposits resulling from sheet erosion of cultivated fields also are part of the Recent alluvium, and a few of the more prominent of these have been mupped (Pl. I).

The Recent alluvium is well exposed in the banks of Brushy Croek for a short distance above and below road 337 . Its urconformable relation to the underlying terrace alluvium and soil may be seen at an outcrop at the first bend of the creek below the southern end of the ncw channel about 900 feet downstream from gaging station J, and also at a bend at approximate Lat. $31^{\circ} 28^{\prime} 10^{\prime \prime}$, Long. $96^{\circ} 51^{\prime} 15^{\prime \prime}$, about halfway belween gaging station $\mathrm{J}$ and road 337 .

Unlike the terrace alluvium, the Recent alluvium consists largely of soil, mixed with variable amounls of sand and gravel if these malcrials occur on the drainage area contributing to the deposit. Pieces of chalk from eroded ficlds, marl from gullies, and gravel from roads are prosent in some deposits. Conscquently on the experimental area this alluvium consists of two main ,types: a brown, sandy type occurring in the nortbwestern. half of the arca and along Brushy Crcek to beyond the limits of the project, and a black, clayey lypo found along the lributary streams draining the southeastern half of the area. The former constitutes the arras of Kaulman and Catalpa soils, the latter of Trinily soil. The sandy type is just beginning to develop a soil profile, thus differing from the profiled residual sandy soils of the region. The black, clayey type, consisting as it does almost entircly of struclureless black soil, is very difficult to distingurish from the residual black soils formed on the adjacent l'ecan Cap marl or terrace alluvial marl, except where it contains thin laminae of "sandier material.

It is noteworthy that the influence of the sandy marls of the Wolfe City member is manifesled farther downstream in the Recent than in the terrace alluvium. In keeping with this slower deposition, visible stratification or lamination is more common in the Recent alluvium, although seldom conspicuous.

A maximum thickness of 12 feet of Recent alluvium has been observed along Brushy Crcek, and it is probably no thicker than 1.5 feel anywhere within the experimental area. 'The broad, gently sloping plain along the creek is built of the Plcistocene terrace alluvium, and although parts of it are occasionally flooded in modern limes, these areas bear only a thin veneer (less than I foot in most places) of Recent deposits. The bulk of the Recent alluvium occupies the zone between the outer limits of the meanders. Within this zone the stream is now flowing on Recent alluvium, and there probably are filled channcls of greater depth, but it is cutting into terrace alluvium and residual marls at most of the outer curves. Although some deposition takes place during cvery flood, the balance at the present time scems to be in favor of erosion of the channel. This is especially true in the Pean Gap area, where there is some ground-waler flow. Fxceptions are found near the junclions of Brushy Creek with its tributaries flowing through gaging stations $\mathrm{Y}$ and $\mathrm{Z}$ (Pl, I), whore deposition seems to have the upper hand. 


\section{Dechyen Rock and SoILS}

Decay of the rochs.-The first stage in the decomposition of the marls and chalks of the experimental area seems to be a proc" css of oxidation, which begins at a depth of 20 to 30 fecd below the surface. Its only jmmediate effect is a change in color from bluish blark or bluish gray to a gray or tan. Erequently mottled with rusty spots or slreaks. $\Lambda$ s the surface is approached differences between different strata become more pronounced, apparently according to their relative iron contenl. 'The sandy marls take on a uniform rusty brown, the highly calcareous marls become brownish gray, and the chalks become little darker than a $\tan$.

In the highly calcareous marls lracturing by the formation of curved cracks following conchoidal surfaces is prominent at depths as great as 25 feet. In the sandy marls the fracture pattern is less regular, and in the chalks it may not appocar at all. At lesser depths the conchoidal fractures in the highly calcareous marl become more and more abundant until finally the entire malerial is broken into closely set lumps half an inch or less in diameter. Further chemical decay scems to accompany this process, so that the marl becomes softer and rustier in color, and then passes im. perceptibly into the yellowish-gray subsoil and from that into the black top-soil, which may be 3 or 4 feet thick. Within the chalk the fractures are more open but farther apart, and the material retains its hardness to within a few feet of the surface, and then changes rather sharply to a white subsoil and a shallow black top-soll. The sandy marls behave much like the highly calcareous marl, the rusty brown color continuing into the subsoil.

Relation between parent rocks and soils. -A description of the soils of the experimental area and a detailcd conservation survey map showing their distribution may be found in Hydrologic Bulletin 5 (Baird, Lauritzen, et al., 1942). $\Lambda$ comparison of this map with the geologic map of this paper (Pl. I) will show the intimate relation of the soils to the geology.

A residual soil may be regarded as the result of five principal factors, namely, parent material, climate, vegetation, topography, and length of time through which a particular set of these influences has been operative. For mature soils the cumulative effect of climate often outweighs most of the other factors, thus tending to produce more or loss uniformity in all the soils of a particular climatic region. This parl of Texas lies just within the zone of the pedalfer soils, that is, the rainfall at the prevailing temperaluses is sufficient to remove all the soluble salts, including calcium carbonate, from the soils derived from most geologic materials. The purer marls and chalks of the Cretaceous formations, howcver, present material which is abnormally rich in calcium carbonate and unusually easily weathered. As a result the prevailing rainfall carnot remove all the calcium carbonats, and calcareous sojils (rendzinas) are produced in the pedaller climatic zone. $\Lambda$ slight decrease in the proportion of calcium carbonate in the parent material permits its complete removal from the surface layers of the resulting soil. The introduction of sand from the parent malcrial increases the penetration of the rainfall and promoles the development of definite horizons by differential shifting of some of the finer constituents. Thus comparatively slight changes in the lithology of the underlying sediments are very closely reflected in the residual soils derived from them. Fxact correspondence is prevented by the effects of other factors, here chiefly topography as it controls drainage.

As shown on maps in Hydrologic Bullelin 5 (Baird, Lauritzen, et al., 1942), the Houston soils, which are calcareous throughout the profile, form on the chalks and the highly calcareous marls of the Pecan Gap member, as well as on that portion of the alluvial marl which has been derived chiefly from these strata. They are found also on the silly marl of the Wolfe City member in spite of its lower calcium carbonate content, probably because the invisible silt is too fine, and the clay content too high, to permit much internal leaching.

The Houston-Hunt soils are found on the sandy marl of the Wolfe City member. The streaked development of these soils seems to bear no relation to any variation in the lithology of the parent material and is without adequate explanation. 
The Crockett soils develop on some parts of the area underlain by the sandy marl of the Wolfe City member. There is some reasun to believe that within the experimental area these soils owe their greater degree of leaching to an admixture of sand from ancient alluvial deposits, now almost completely. eroded, but the evidence is inconclusive.

Within the project area the Wilson soils are confined almost entircly to those parts of the terrace alluvium derived wholly or chiclly from the Wolfe City strata. They occur also here and there on the flatter parts of the uplands, probably because of poor drainage, where as far as has been determined no alluvium exists.

The Recent alluvium consists largely of transported soil, and the soils now forming on it (Trinity and Catalpa) are in early stages of development. It should be em. phasized that almost all the soil on the ter. race (oIder) alluvium has not been transported as soil but has formed in place as residual soil from alluvial parent material.

Concretions and similar bodies.-Con. cretions are common in the subsoil and in the zone of decayed rock beneath it throughout the experimental watershed. They are related both to the nature of the rock and to the processes of soil formation and are of several types.

Hard, Hlack spheres one-cighth to onefourth inch in diameter occur extensively in the subsoil on the sandy marl, particu. larly in the northern part of the watershed where the sand in the marl is coarser and more abundant. Qualitative chemical tests indicate that they consist chiefly of iro: and manganese oxides, cementing parlieles of sand.

Calcium carbonate concretions occur throughout the walcrshed and are of threc principal types:

Small, hard, irregular concretions occur in the subsoil both in the Houston black clay and in the soils of the Wilson series. They are usually brownish or tan and seldom exceed half an inch in diameter. They have an irregular and lumpy surface as if composed of aggregates of smaller indi. viduals.

Smooth, hard, rounded concretions are often found deeper in the subsoil and in the zone of decayed marl in areas underlain by the mo:e highly, calcareous marls. They are somewhat softer and whiter than the first type. They are particularly common in the alluvial marl which has been derived from the more calcareous formations.

Soft, white, irregular patches of calcium carbonate also are occasionally found in the zone of decayed rock. In places their texture is sufficiently coarse so that individual crystals can be seen with the naked eye. They scem definitely to result from the leaching of calcium carbonate from higher layers by descending waters and its redeposition in crevices and openings below. Thus they are commonly found in the first few feel of the silty marl below the chalk wherever the contact between these strata lies in the zone of oxidation (Pl. III). They partake more of the nature of deposits of caliche than of concretions.

Crystals of gypsum, both loose and in aggregates, are commonly found in the sandy and silty marls throughout the zone of oxidation. 'The evidence is insufficiont to show whether they are the result of soil. forming processes or of the oxidation of marcasite in place.

\section{Analytical Data}

In order to investigate the fundamental differences existing between the various slrata underlying the project area and to stiudy their relation to the soils and to the ground water, certain chemical, mechanical, and microscopic studies were made upon representative samples sclecled from the auger holes and excavations.

Two samples were studied from each of the important subdivisions (except the upper chalk and the vpper highly calcareous marl) of the Cretaccous strata above described, one of unoxidized material and the other of oxidized material from a location calculated to represent as nearly as possible the same stratigraphic horizon, assuming a strike of N. $20^{\circ}$ E. and a dip of 80 feet per mile. In addition one unoxidized sample each was taken from the upper chalk, the glauconitic portion of the lowce chalk, and the hard calcareous sandstone, and one sample from each of the two types of terrace alluvium. Material from a single depth or run in a parlicular hole was used, and from this, undisturbed lumps were, selected wherever possible. A thim section was made from one of the lumps 


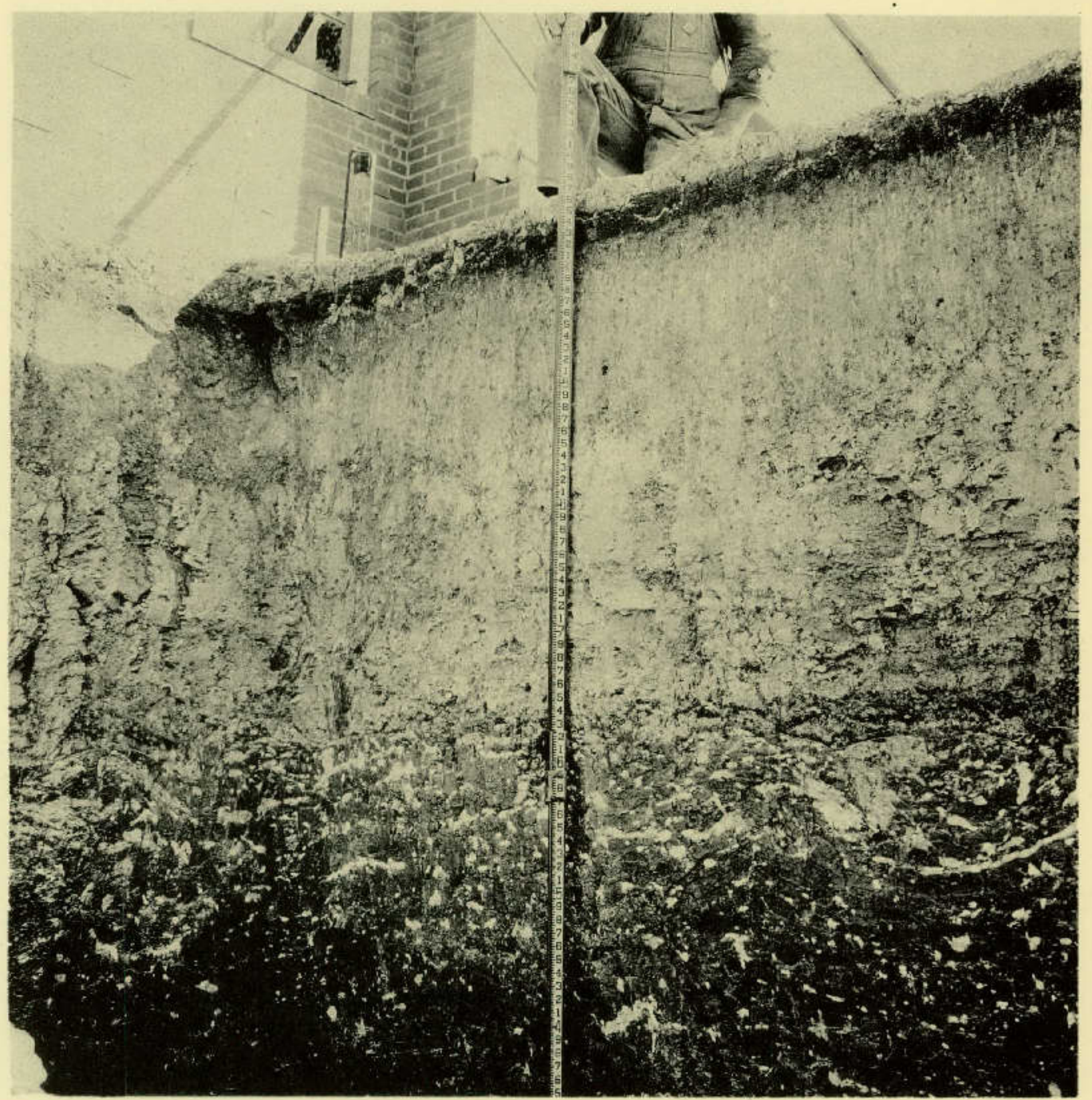

Contact of Pecan Gap chalk (above) with Wolfe City silty marl (dark, below), showing soft white calcium carbonate leached from the chalk and deposited in crevices in the marl. Excavation for settling tank at project laboratory. Soil Conservation Service photographs No. $20,197-A$ and $20,197-B$. 

in each sample. The remaining lumps were crushed to about $5-\mathrm{mm}$ size and quartered, and a 50-gram portion was taken for acid treatment. About 10 grams of the remainder of each sample were finely ground for chemical analysis.

The 50.000-gram samples of the airdried, crushed material were treated with an excess of 1:5 hydrochloric acid at room temperature, allowed to stand overnight, brought to boiling, allowed to settle, fil. tered, and washed. Because preservation of the glauconite was desired, sample No. 6 was treated with $1: 5$ acetic acid instead of hydrochloric. The insoluble residues were dried at 100 to $110^{\circ} \mathrm{C}$. and weighed, and samples from them were used for the mechanical analyses. The filtrates were diluted to $1500 \mathrm{cc}$, and one-tenth aliquots, representing 5.000 grams of original material, were used for the delermination of acid-soluble sulfatc.

The other chemical determinations were made on the finely ground, air-dried, original material. Carbonates and silica were determined as most likely to reveal fundamental differences in composition of the sirata. Sulfates and chlorides were investigated because of the presence of the corresponding ions in the ground water in large amounts.

Carbonates were determined by evolution and absorption of $\mathrm{CO}_{2}$ according to the method of Shaw (1931), except that 1:6 $\mathrm{HCl}$ was used instead of 1:9. A sep. arate sample of about 3 grams was fuscd with sodium carbonate, dissolved in dilute nitric acid, and chlorides determined in this solution as recommended by Fillebrand (1919, pp. 220-221 and 231-232). After removal of the excess silver, the filtrates were evaporated with $\mathrm{HCl}$ and the silica determined in this residue and in the residue insoluble in nitric acid by difference alter volatilization with $\mathrm{HF}$. Total sulfur was determined as sulfate in the $\mathrm{HCl}$ solution after removal of the silica.

Mechanical analyses of the acid-insolu. ble residues from the original samples wcre first carricd out by the method of Olmstead, Alexander, and Middleton (1930, pp. 14-20) for the mechanical analysis of soils. "The "sand" fractions obtained, however, especially from the chalks and highly calcareous marls, consisted largely of sill and clay aggregates, and it was evident that complete dispersion had nowhere nearly been attained. Also, the marcasite in the unoxidized samples caused them to react violently with the hydrogen peroxide used in this method for the removal of the organic matter and to require excessive amounts of this reagent.

The object of the mechanical analyses was primarily to test the conclusions reached in the ficld regarding the relative amounts of sand in the different strata of the Pecan Gap and the Wolle City members, and also to oblain sand fractions clean enough for microscopic study of the constituent minerals. Complete separation of clay from the sands was therefore essential. It seemed possible that the incomplete dispersion of the silt and clay might be due to a little gelatinous silicic acid which rnight have been formed by the acid treatment of the original material. This suggested that sodium carbonate might aid the dispersion. Treatment of some of the insoluble residues with sodium carbonate, followed by decantalion and washing, resulted in much cleaner sands. It was also noticed that during the hydrogen peroxide treatment by the standard procedure of Olmstead, Alexander, and Middleton, the evolution of great numbers of minute gas bubbles in the violent reaction with the unoxidized samples helped to break up the aggregatcs and produced cleaner sand fractions than those from the already oxidized material. As a result of these observations a procedure was devised using both sodium carbonate and the cvolution of a gas, even though il was realized that the former might not confine its solvent powers to any finely divided silica which might have been artificially produced.

Attempts werc first made to remove the organic matter by extraction with carbon bisulfide. ${ }^{8}$ Alcohol was found somewhat more effective, but neither reagent removed the organic matter completely. After drying and reweighing, the sample was shaken with a 10 -percent solution of sodium carbonate for 20 to 24 hours, decanted, and washed once by decantation. The residue was then treated with a roughly equimolecular mixlure of powdered sodium nitrate and ammonium chloride, with a

\footnotetext{
${ }^{8}$ Cotripare Miluer (1940, pp. 195-196). A Soyblet ex tractor was ubed inatead of the funnels dcseribed in this book.
} 
Tance 2. Description of Samples Arulyzed

\begin{tabular}{|c|c|c|c|c|}
\hline $\begin{array}{c}\text { Sumple } \\
\text { No. }\end{array}$ & Hole No, & $\begin{array}{l}\text { Elevation of } \\
\text { ground sturface } \\
(\text { feet })^{2}\end{array}$ & $\begin{array}{l}\text { Depll of } \\
\text { sample } \\
\text { (feet) }\end{array}$ & Formation and description \\
\hline 1 & 1000 & 454 & 14 & $\begin{array}{l}\text { 13ecun Cap. Culculated to be } 116 \text { leet above the } \\
\text { base of this formation. Soft chalk. Light bluc } \\
\text { gray. Unoxidized. No sill or sand visible to } \\
\text { naked eye or deleclable on chewing. }\end{array}$ \\
\hline 2 & 1010 & 463.2 & $86.6-89$ & $\begin{array}{l}\text { Pecan Gap. } 56.5 \text { to } 58.9 \text { fcet above basc of this } \\
\text { formation in this hole. Higbly calcareous marl. } \\
\text { Blue gray. Unoxidized. No silt or sand visible } \\
\text { to naked eye or detcctable on chewing. }\end{array}$ \\
\hline 3 & 413 & 488.1 & 16.7 & $\begin{array}{l}\text { Pecan Gap. Calculated to be } 57 \text { feet above base } \\
\text { of this formalion. Highly caleareous marl. } \\
\text { Gray white and light tan. Oxidized. No silt } \\
\text { or scind visible to naked eye or detcetable on } \\
\text { chewing. }\end{array}$ \\
\hline 4 & 1010 & 463.2 & $3.41 .2-112.3$ & $\begin{array}{l}\text { I'eran Crap. } 3.2 \text { to } 4.3 \text { fect above base of this } \\
\text { formation in this hole. Chalk. Light bJue gray. } \\
\text { Unoxidized. No silt or sand visible to niked } \\
\text { eye; a litule detectable as grit on rhewing. }\end{array}$ \\
\hline 5 & 666 & 557.3 & $24.5-25$ & $\begin{array}{l}\text { Pecali Gap. } 3.25 \text { to } 3.75 \text { feet above base of this } \\
\text { formation in this holc. Chalk. Gray while } \\
\text { with rusty strcaks. Oxidized. No silt or sald } \\
\text { visible to naked eye; traces of grit on chewing. }\end{array}$ \\
\hline 6 & 694 & 506.8 & 50 & $\begin{array}{l}\text { Pecan Cap. } 0.85 \text { lool above base of this forma- } \\
\text { tion in this hole Glauconitic chalk. Ifight } \\
\text { bine gray, with dark green sperks. Unoxi- } \\
\text { dized. No silt or sand visible to naked eye; it } \\
\text { litule detectable as grit on rhewing. }\end{array}$ \\
\hline 8 & 1.010 & 463.2 & $15.5 .8-157.7$ & $\begin{array}{l}\text { Wolf. City. } 10.3 \text { to } 12.2 \text { feet below base of Pccan } \\
\text { Gap in this hole. Silty marl. Blue gray to } \\
\text { greenish gray. Innidized. No silt or sand } \\
\text { visible to naked eye; much finc grit on chew- } \\
\text { int. }\end{array}$ \\
\hline 9 & TW-I & 522.5 & 15.7 & $\begin{array}{l}\text { Wolfe City. Calculated to be about } 15 \text { feet } \\
\text { below base of Pccen Gap. Silly marl. Brown. } \\
\text { ish gray to pale rusty. Oxidized. No silt or } \\
\text { sand visible to naked eye; much fine grit on } \\
\text { chewing. }\end{array}$ \\
\hline 13 & 1011 & 526.4 & $1.13 .8-116 . \mathrm{t}$ & $\begin{array}{l}\text { Wolfe City. } 95.6 \text { to } 97.9 \text { fect below base of Pecam } \\
\text { Gap in this hole. Sandy marl. Blue gray. } \\
\text { Inoxidized. Sand visible to naked eyc. }\end{array}$ \\
\hline 14 & 256 & 553.6 & 10.7 & $\begin{array}{l}\text { Wolfe City. Calculated to be } 95 \text { leet below base } \\
\text { of Pecan Gap. Sandy marl. Brownish gray to } \\
\text { pale rusty. Oxidized. Sand visible to naked } \\
\text { cye. }\end{array}$ \\
\hline 17 & 1011 & 526.4 & $161.8-163.5$ & $\begin{array}{l}\text { Wolfe City. 1.3.6 to } 145.3 \text { feet below base of } \\
\text { Pecan Gap in this hole. Sandy marl with sand- } \\
\text { stone lenses. Blue gray. Unoxidized. Sand } \\
\text { visible to naked cyc; contains pieces or hard } \\
\text { calcareous sandstone also. }\end{array}$ \\
\hline 18 & 807 & . 542.6 & 11 & $\begin{array}{l}\text { Wolfe City, Calculated to be } 144 \text { fect bclow base } \\
\text { of Pecan Gap. Sandy marl with sandstone } \\
\text { lenses. Brownish gray to rusty. Oxidized. } \\
\text { Sand visible to naked eye; contains pieces of } \\
\text { hard calcareous sandstone glso. }\end{array}$ \\
\hline 19 & 1011 & 526.4 & $182.1-183.7$ & $\begin{array}{l}\text { Wolfe City. } 164.2 \text { to } 165.5 \text { feet below basc of } \\
\text { Pccan Gap in this hole. Hard calcareans sand- } \\
\text { stonc. Grayish blue. Unoxidized. Visible sand } \\
\text { firmly cemented with crystalline carbonate. }\end{array}$ \\
\hline 20 & $\begin{array}{l}\text { Reservoir } \\
\text { Test Pit } \\
3\end{array}$ & 511.7 & $6.3-7.6$ & $\begin{array}{l}\text { Terrace alluvium. Overlios highly calcareous marl } \\
\text { of I'ecan Gap. Alluvial marl, highly calcareous } \\
\text { typc. Gray with rusty and black spots. Oxi- } \\
\text { dized. Sand generally not visible; very gritty } \\
\text { an chewing; occasional pcbbles. }\end{array}$ \\
\hline 21 & Soils Pit I0 & 507 (est.) & -11.7 & $\begin{array}{l}\text { Terrace alluvium. Overlies sandy marl of Wolle } \\
\text { City. Alluvial marl, fine sandy type. Varie- } \\
\text { pated gray and pale rusty. Oxidized. Sand } \\
\text { just visible to naked eye; very grity an chew- } \\
\text { ing; no pehbles. }\end{array}$ \\
\hline
\end{tabular}

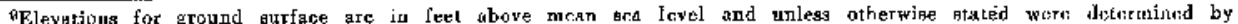
levelling from brinch marks based wron tie U. S. Cosst and Geodetic Survey B. M. near lue raijoosd station at Ricsil, 'Tixat. 
TABLE 3

Parial chemical analyses of rock materials. Analyzed by H. R. Blank and N. L. Stolienberg.

\begin{tabular}{|c|c|c|c|c|c|c|c|c|c|c|}
\hline $\begin{array}{c}\text { Sample } \\
\text { No. }\end{array}$ & $\begin{array}{c}\text { Total } \\
\mathrm{SiO}_{2}\end{array}$ & $\mathrm{CO}_{2}$ & $\begin{array}{l}\text { Moisturea at } \\
100-110^{\circ} \mathrm{C}\end{array}$ & $\begin{array}{c}\text { Residue } \\
\text { insoluble } \\
\text { in } 1: 5 \mathrm{HCl}\end{array}$ & $\begin{array}{l}\mathrm{CaCO}_{3} \\
=\mathrm{CO}_{\mathrm{a}} \\
\left(\mathrm{cal} \mathrm{C}_{\mathrm{n}}\right)\end{array}$ & $\begin{array}{c}\mathrm{SO}_{4} \text { solublo } \\
\text { in } 1: 5 \mathrm{HCl}\end{array}$ & Total $C_{d}$ & Totall S & $\begin{array}{c}\text { Sulfur } \overline{-} \\
\text { soluble SOA } \\
\text { (calc.) }\end{array}$ & $\begin{array}{c}\text { sulfide S } \\
\text { (cale.) }\end{array}$ \\
\hline 1 & 15.39 & 31.55 & 1.71 & 13.37 & 71.75 & 0.078 & 0.024 & 0.340 & 0.026 & 0.314 \\
\hline 2 & 30.46 & 19.46 & 4.05 & 47.53 & 44.25 & .0 .190 & 0.040 & 0.734 & 0.064 & 0.670 \\
\hline 3 & 26.23 & 23.06 & 2.98 & 38.84 & 52,44 & 0.010 & 0.048 & 0.040 & 0.003 & 0.037 \\
\hline 4 & 15.80 & 32.13 & 1.4 .5 & 22.14 & 73.06 & 0.105 & 0.069 & 0.373 & 0.035 & 0.3388 \\
\hline 5 & 11.65 & 33.95 & 1.66 & 16.80 & 77.21 & 0.031 & 0.013 & 0.044 & 0.010 & 0.034 \\
\hline 6 & 11.90 & 33.59 & 1.54 & $20.99 \mathrm{~b}$ & 76.38 & 0.142 & 0.066 & 0.469 & 0.047 & $0 . l, 22$ \\
\hline 8 & 48.91 & 6.56 & 5.36 & 72.95 & 14.92 & 0.229 & 0.120 & 1.063 & 0.076 & 0.987 \\
\hline 9 & 49.76 & 10.39 & 4.33 & 64.91 & 23.64 & 0.018 & 0.064 & 0.066 & 0.006 & 0.060 \\
\hline 13 & 63.24 & 3.14 & 3.53 & 81.86 & 7.14 & 0,231 & $0.17]$ & 0.805 & 0.077 & 0.728 \\
\hline 14 & 60.87 & 2.56 & 4.64 & 80.45 & 5.83 & 0.029 & 0.036 & 10.064 & 0.010 & 0.054 \\
\hline 17 & 60.48 & 3.13 & 3.37 & 81.98 & 7.11 & 0.235 & 0.050 & 0.790 & 0.078 & 0.712 \\
\hline 18 & 61.72 & 5.90 & 2.72 & 75.28 & 13.42 & 0.137 & 0.162 & 0.139 & 0.046 & 0.093 \\
\hline 19 & 59.18 & 14.78 & 0.88 & 61.58 & 33.61 & 0.031 & $0.05]$ & 0.283 & 0.010 & 0.273 \\
\hline 20 & 33.70 & 21.48 & 3.34 & 43.09 & 48.86 & 0.078 & 0.119 & 0.087 & 0.026 & 0.055 \\
\hline 21 & 61.41 & 5.50 & 4.22 & 74.67 & 12.51 & 0.039 & 0.112 & 0.139 & 0.013 & 0.126 \\
\hline
\end{tabular}

a 11 porrento ges caleulated on weight of air-dried emmple.

th: 5 acetic acid used instend of bydrochloric.

Table 4

Mechanical analyses of insoluble residues from acid treutment of rorls materials. (A. J. Stewart, Jr., and J. E. Poug, analysts)

\begin{tabular}{|c|c|c|c|c|c|c|c|c|c|c|c|}
\hline $\begin{array}{c}\text { Sample } \\
\text { No. }\end{array}$ & $\begin{array}{l}\text { Moigture at } \\
100-110^{\circ} \text { C. }\end{array}$ & $\begin{array}{c}\text { Organic } \\
\text { matter by CSy } \\
\text { and alcohal }\end{array}$ & $\begin{array}{c}\text { Fine gravel } \\
(>1 \mathrm{~mm})\end{array}$ & $\begin{array}{c}\text { Coarse sand } \\
(<1 \mathrm{~mm} \\
>0.5 \mathrm{~mm})\end{array}$ & $\begin{array}{c}\text { Medium sand } \\
(<0.5 \mathrm{~mm} \\
>0.25 \mathrm{~mm})\end{array}$ & $\begin{array}{c}\text { Finesand } \\
(<0.25 \mathrm{~mm} \\
>0.1 \mathrm{~mm})\end{array}$ & $\begin{array}{c}\text { Very fine sand } \\
(<0.1 \mathrm{~mm} \\
>0.05 \mathrm{~mm})\end{array}$ & $\begin{array}{c}\text { Silt } \\
(<0.05 \mathrm{~mm} \\
>0.002 \mathrm{~mm})\end{array}$ & $\begin{array}{c}\mathrm{C} a \mathrm{ay} \\
(<0.002 \mathrm{~nm})\end{array}$ & $\begin{array}{c}\text { Screcning } \\
\text { loss }\end{array}$ & Total. \\
\hline 1 & 8.46 & 1,22 & None & 0.03 & 0.15 & 0.33 & 0.28 & 14.68 & 56.72 & 0.07 & 81.94 \\
\hline 2 & 7.04 & 0.28 & Traces: & None & Trace & 0.02 & 0.06 & 19.37 & 65.19 & None & 91.96 \\
\hline 3 & 8.28 & 0.24 & None & None & Trace & 0.03 & 0.09 & 16.03 & 65.64 & 0.112 & 90.33 \\
\hline 4 & 6.08 & 0.76 & None & Truce & Trace & 0.19 & 6.84 & 29.54 & 48.81 & 0.15 & 92.37 \\
\hline 5 & 8.14 & 0.61 & None & Trace & Trace & 0.26 & 1.43 & 24.97 & 56.19 . & 0.68 & 91.68 \\
\hline 6 & 7.08 & 0.54 & $0.03 \mathrm{at}$ & 0.08 & 0.32 & 2.42 & 5.07 & 23.88 & $48.4 \mathrm{I}$ & $(.03)^{\circ}$ & 87.80 \\
\hline 8 & 6.75 & 0.38 & None & Trace & Trace & 0.03 & 0.12 & $32,1.2$ & 50.95 & 0.04 & 90.39 \\
\hline 9 & 5.61 & 0.30 & Noute & None: & Trace & 0.05 & 1.57 & 45.05 & 40.34 & 0.12 & 93.04 \\
\hline 13 & 4.26 & 0.48 & None & None & 'race & 5.70 & 24.53 & 25,46 & 31.71 & 0.12 & 92.26 \\
\hline 14 & 5.60 & 0.26 & Nonte & None & Trace & 2.96 & $16.0 \mathrm{l}$ & 28.71 & 36.54 & 0.10 & 90.18 \\
\hline 17 & 5.56 & 0.89 & None & None & Tracc & 0.73 & 12.64 & 35.18 & 34.30 & 0.14 & 89.44 \\
\hline 18 & 5.34 & 0.59 & None & Trace & 0.08 & 14.13 & 16.73 & 23.54 & 30.83 & 0.20 & 91.44 \\
\hline 19 & 1.34 & 0.57 & None & 0.05 & 1.06 & 65.25 & 9.49 & 10.40 & 9.34 & 0.21 & 97.71 \\
\hline 20 & 8.99 & 0.59 & $2.85^{\mathrm{t}}$ & 1.81 & 4.87 & 6.91 & 3.40 & 18.47 & 41.05 & 0.15 & 89.09 \\
\hline 21 & 6.87 & 0.53 & 0.27 & 0.47 & 0.72 & 2.64 & 10.66 & 35.41 & 31.75 & 0.16 & 89.98 \\
\hline
\end{tabular}

${ }^{2}$ All precentages calculated on weight of ait-dritula sumple of insoluble regifues.

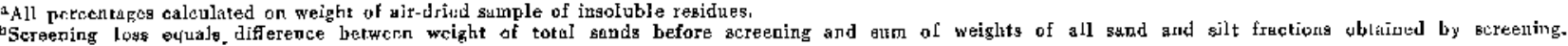

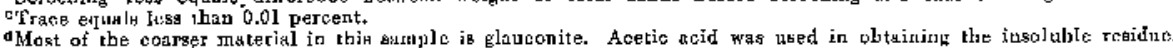


very little water, and warmed, which produced a frothy evolution of nitrogen and assisted the dispersion without creating an oxidizing environment. A portion of the decanted sodium carbonate solution was then returned to the mixture, and the material was shaken again for 20 to 24 hours and then filtcred through a porous cylinder (Pasleur-Chamberland filter) and washed with water. The dark brown color of many of the filtrates indicated that considerable additional organic matter was removed by the sodium carbonate.

As the sample dispersed on washing it began to clog the filter, and it was soon evident that all the soluble salts could not be removed in this way. The material was therefore washed off the filter into an electro-dialysis apparatus and dialyzed, with frequent changes of water, until the liquid gave no test for chlorides and was not alkaline to phenolphthalein.

Upon removal of the sample from the dialysis apparatus it was observed that the clay, flocculated by the electrolysis, dispersed very incompletcly in a small volume of water, but that after diluting to between one and two liters dispersion readily took place. The suspension was then allowed to stand overnight, a period more than sufficient, as calculated from Stokes's law, for all the silt to settle in the depth of liquid used. The cloudy supernatant liquid was then carefully siphoned off, and the process was repeated until most of the clay had been removed. In the residue the sands, silt, and remaining clay were separated and determirued by the standard procedure of Olmstead, Alexander, and Middleton above referred to, except that no sodium oxalate was"added, no metallic jons being present. The clay which had been siphoned off was flocculated by electrolysis, dried, and weighed.

It is belicved that the method used gives a much truer estimate of the actual sand conlent of the insoluble residues than the standard procedure al first tried, but, as may be seen from table 4 , it involves a loss of about 10 percent of the material (in one case as much as 18 percent). Weighing the samples at any point between the first dispersion and the final determinalions was avoided because of the effect of drying in floceulating the clay, but separate tests indicated that solution by the sodium carbonate was responsible for most of the loss. In addition to any possible gelatinous silicic acid, the sodium carbonate may have attacked the fine sill as well as the clay and the organic matter. Unfortunalely neither time nor material was available for more complete investigation of the minimum strength of sodium carbonate required to effect complete dispersion of the insoluble residues, either with or without the aid of the evolution of nitrogen, and of the extent to which solution would take place at that minimum concentration.

Microscopic examination showed the sand and silt grains in most of the fractions to be very clean. Silt aggregates, and even grains of clay minerals of silt size, were still numerous in the coarser fractions of samples nos. 4, 5, and 17, and glauconite aggregates in no. 6. Most of the marcasite abundant in the unoxidized samples came through unscathed.

Throughout the analyses much difficulty was caused by the hygroscopic nature of the material and its tendency to adjust its moisiure content to that of the atmosphere. Weights after successive dryings were never the same, but the variation could be brought to within less than 0.05 percent during a period of steady dry weather. Even on the finely ground original rocks, samples for the diflerent determinations had to be weighed out on the same day in order to be strictly comparable.

Incomplete as the analyses are, they indicate some interesting generalizations. The extreme fineness of practically all the rock material in the experimental area, especially in the highly calcareous marl, is shown by the mechanical analyses, which thus confirm the conclusions drawn in the field by chewing tests. It is noteworthy, however, that all samples contain large amounts of silt as well as clay. The chernical determinations show the more calca cous nature of the Pccan Gap mem. ber as compared with the Wolfe City rromber. The upper chalk is very similar in composition to the lower, although in appearance the material of the sample closely resenbles the highly calcareous marl.

The local origin of the alluvial marls is well shown by their resemblance in both chemical and mechanical composition to 



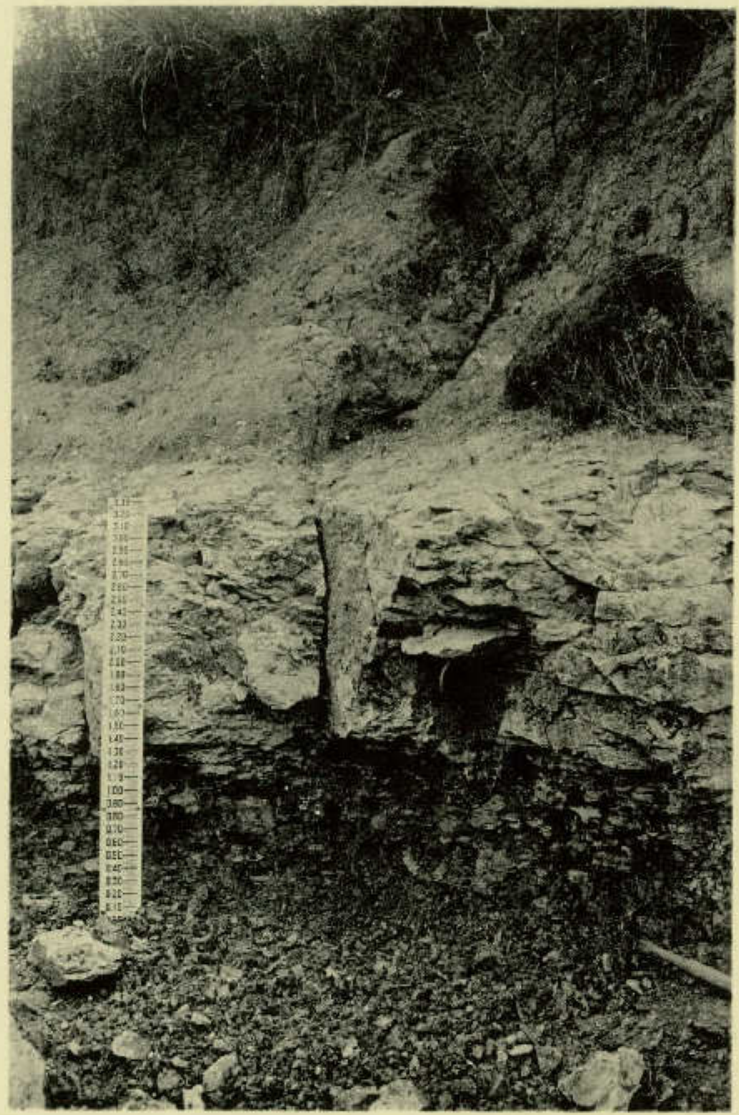

Contact of Pecan Gap chalk (center) with Wolfe City silty marl (below). Chalk overlain by alluvium. Big Sandy Creek, three-fourths of a mlle north of St. Paul's Church, Falls County, Texas (loc. 6, PI. II). Soll Conservation Service photograph No. 20,566. 
the residual strata in the vicinity, and the calcareous and sandy types are sharply 'differentiated. In both types, however, their alluvial origin is indicated by the wider distribution of sand sizes.

The sandiness of sample no. 6 is due largely to glauconite.

The high content of silt and clay, together with absence of coarser sand, shown by samples no. 8 and 9 , agrees with the properties of this zone of silty marl at the top of the Wolfe City member.

Much of the ground water of the project area is known to be high in sulfates and chlorides. Since gypsum crystals have been observed at many places in the strata in the zone of oxidation, expecially in the Wolfe City member, it was thought that the analyses might show a rather wide distribution of soluble sulfates in this zone, although visible gypsum was avoided in selecting the samples. However, the analy. ses indicate rather clearly that the oxidized zone has been leached rather than en. riched in chlorides and sulfates, and that the marcasite and possible connate water in the unoxidized marls and chalks are the ultimate sources of these soluble materials.

\section{Structural Fieatures}

In conformity with the general structure of the Gulf Coastal Plain, the Cretaceous strata on the experimental watershed dip toward the Gulf of Mexico at angles a little greater than the general slope of the land surface, and their belts of outerop therefore tirn toward the southeast wherecver the land is lower and toward the northwest where it is higher (Pl. I). This has been ascertained in a general way for the Cretaceous rock types above described by numerous auger holes bored throughout the area to shallow depths. The exact attitude of the beds has been much more diff. cult to determine because of the impossibility of identilying individual strala. No key beds identifiable in different parts of the experimental area have been found, except the lower chalk of the Pecan Gap nember. The ipper edge of this is indefinite, and only its lower edge, its contacl with the underlying silty marl, can be readily identified al: all places.

This contact. between the Pecan Gap member above and the Wolfe City member below is stated to be an unconformity in northeast Texas by Stephenson (1918, p. $156 ; 1929$, p. 1330) and by Ellisor and Teagle (1934, pp. 1517 and 1528). The latier authors apparently believed this break to be of wider geographic extent.

Certain evidence from the cxperimental watershed tends to confirm this view. As already noted, glauconite was found in the lowermost $\mathrm{I}$ or 2 feet of chalk in all exposures, except where it might easily have becn removed by oxidation. In hole 1010 , just southeast of the experimental area, and in hole 1020 on Brazos River, where the contact was cut in unoxidized material, fragments of silty marl were found in the lowermost few inches of cha]k. Cylindrical bodies of chalk extended down for as much as 16 inches into the underlying silty marl and probably represent filled burrows of marine animals.

On the other hand, both in these holes and at the oulcrops on Big Sandy Creek (P1. IV), lenses of glauconitic chalk were found in the uppermost foot of the silty marl and are not easy to explain unless the contact is somewhat transitional. In hole 694, near the extreme southern end of the experimental area, lenses and streaks of silty marl were first encountered at depth 42 fect. With increasing depth these gave way to chalk again, and another and sharper contact with the silty marl was found at depth 51 feet. But at all other places the change from chalk to' silty marl was Jound entirely complete' within 2 feet, and at most places within 6 inches.

It thus appears, that the one and only identifiable stratigraphic marker on the experimental area probably represents an unconformity and thereforc a surface which would be expected to be irregular as the result of erosion, "whether submarine or subaerial. Before this was realized the dip and strike of this conlact were deiermined by calculations from a large number of borings, assuming it to be a plane and determining its posilion from the location and elevation of any three known points. The results, while not entirely harmonious, were sufficiently so to indicate that at least in this vicinity this surface strikes between N. $10^{\circ}$ E. and N. $20^{\circ}$ E. and dips cast by south at about 80 feel to the mile, and that it probably departs but little from the actual strike and dip of the strata. 
All the alluvial deposits described above are unconformable with the Cretaceous strata and with each other.

Minor faults are present at many places throughout the experimental area, but there is no evidence that any of them have affected the geologic structure to any great extent. Those shown in Plate I were in. dicatcd from surveys of the chalk-silty marl contact, irregulitr results in the calculated dip, and the presence of unusual amounts of ground water, but in none of them could the displacement exceed 10 leet, and it is probably much less. Because of the known presence of minor faults and the alignment. of some of the tributary valleys, search was made for some displacement of groater magnitude, but no evidence of any such was found, and the drainage pattern is hest attributed to differential erosion along the strike of the harder and softer beds.

Minor faults can best be scen in the outcrops of chalk because of the brittleness of this material, but they undoubtedly occur also in the highly calcarcous marl, and probably in the sandy marl as well. In the more brittle materials the faulting leaves open spaces which become filled with calcite, flat pieces of which appear in the overlying residual soil. On these pieces casts of the slickensides are often preserved. In the marls, because of their more elastic nature, fault movements are usually recorded only as narrow, closed joints along which a little oxidation and decay have taken place, often indicated by a rusty stain. Joints probably resulting from similar but still more minor disturbances arc found in the chalk and in the harder portions of the marl. In tho chalk some of these remain open and become channels for the circulation of ground water.

The characteristic conchoidal fracture of the marl and most of the fractures in the chalk seem to be more the result of weathering than of earth movements and to be due in large measure to an expansion and contraction connected with different degrees of hydration. Marl brought up from the unoxidized zone checks and crumbles when exposed to the air, apparently because of shrinkage from loss of moisture. The surface soil in the blacklands exhibits this change in volume with change in moisture content to a remarkable degree, so that in dry weathcr deep cracks up to scveral inches wide form in all areas of undisturbed soil. It would appear, then, that the zone of oxidation represents the total thickness of the rock and soil affected by seasonal changes in moisture content, and that below this zone the only joints present are those due to earth movements. This view is supported by other evidence indicating that the ground water is almost entirely confined to the cracks and joints of the zone of oxidation and that, at least in the chalk and the highly calcareous marl, frec water is entirely absent at greater depths. The distribution of the ground water therefore may be bolth the result and the cause of the manner of weathering of the rock.

\section{PECAN GAl' CHALKS IN THE ADJACENT REGIONS}

The various members of the Taylor marl in central Texas are discussed by Adkins in "The Geology of Texas" (I933, pp. 463-467). These include, in McLennan and Falls counties, a basal highly calcare. ous marl just above the Austin chalk (Burdilt marl), overlain by a sandy marl which south of Brazos River has been called the Durango sand by Danc and Stephenson (1928). North of the Brazos a sandy marl appears a litle higher in the section and has been regarded by the same authors as a southern extension of the Wolfe City sand. This is the sandy marl occurring on the watershed area. $O_{n}$ the east side of the Brazos, at Marlin and cxtending from there north-northeastward through Falls, McLernan, and Limestone counties, several chalk oulcrops have been included in the Marlin chalk by Dane and Stephenson. Above these chalk strata the section consists of marl to the base of the Navarro group. Soulh of the Brazos in central Falls County a similar chalk was named the Lott chalk by Dane and Stepherison, and still farther south the Rogers chalk of Adkins and Arick (1930, pp. 65-66) occurs in Bell County.

Ellisor and Teagle (1934) corrclated all these chalks with the Pecan Gap chalk of east Texas on the basis of their foraminifera, and the names Lott and Marlin were subsequently abandoned by the U. S. Geological Survey. Ellisor and Teagle discuss 
the unconformity and the change in the microfauna betwecn the Pecan Gap inember and the underlying Wolfe City member and state that no similar break in the microluuna occurs between this contact and the basal part of the Nacatoch sand of the Navarro group. Dane and Stephenson, however, believed the Marlin chalk on a lithologic basis to be only about 50 feel thick and to be overlain by 250 feet or more of upper Taylor marl.

The geologic map of T'exas (Darton et al., 1937) shows a conlinuous strip of Pecan Gap chalk from Red River County to south of Colorado River. It is shown as aboul three-fourths of a mile wide in southeastern McLenran Counly and as passing just west of Mart and crossing the $\mathrm{Mc}$ Lennar.Falls County line along the valley of Big Creek.

The contact between the lower chalk and the underlying silty marl, which passes through the experimental watershed, has been traced by the present authors from Big Creek to Brazos River. That this lithologic change corresponds to the microfaunal change from the Wolfe City member to the Pecan Cap member is indicated by the determinations of the microscopic fossils in samples from holes 1010 and 1011 , given in the appendix, which were made at the laboratory of the Humble Oil and Refining Company at Houston, 'Texas, through the courtesy of Messrs. John Teagle and F. W. Rolshausen.

This Pecan Gap-Wolfe City contact is shown by a lino on Plate II. Between outcrops the conlact was traced by means of sceps, crawfish holes, and the character of the subsoil at eroded spots. Dashed portions of the line indicate uncertainty in its location and for the most part represent places where the Cretaceous rocks are obseured by alluvium.

The contact crosses Big Creek between the Riesel-Mart road and the Waco-Mart highway about 1 mile west-southwest of Mart and thence runs in a general southsouthwesterly direction about 2 miles northwest of the position shown on the geologic map of Texas. As would be expected from ils strike of about N. $20^{\circ}$ E. and its east-soulheastward dip, it swings to the east of this general trend where it descends into the valleys of Litlle Brushy, Brushy, and Big Sandy ereeks, and lurns sharply westward to climb the intervening ridges. In the Brazos River bottoms the contact is completely buried by alluvium, but it must cross the river near a sharp bend just below the mouth of Perry Creek and a little over a mile upstream from the traditional "Falls of the Brazos."

The Pecan Gap-Wolfe City contact is not actually exposed in Big Creek, but chalk occurs in a small gully on the west side of the creek at locality 1, Plate II, and silty marl crops out on the right bank about 500 feet upstream. In a small tributary at locality 2 a ledge of the basal chalk is exposed, and by very shallow digging the silty marl may be seen beneath it. $\Lambda$ boring (hole 1001) at this point confrmed the surficial evidence. Glauconitic chalk crops out in the roadside gully at locality 3. The chalk-silty marl contact was cut in digging the new charnel for Brushy Crcek below gaging station $\mathrm{C}$ on the experimental watershed (Pl, I). Two outerops of the herd chalk (but not the basal glauconitic bed) occur on the left bank just below this poinl: (loc. 4, Pl. II), and the transition to highly calcareous marl is well shown in the succceding outcrops, at and downstream from spring well 26 (Pl. I). Chalky subsoil and underlying ledge are exposed in the eroded farmyard al locality 5 (PI. II), where a Pecan Gap outlier caps the hill.

Three excellent exposures of the chalksilty marl contact occur on Big Saridy Creek three-fourths of a mile north of the gravel road passing St. Paul's Church and about the same distance east of the WacoMarlin highway, State highway No. 6 (loc. 6 , Pl. II; Pl. IV). In theso oulcrops, as in holes 1010 and 1020 , lenses of glauconitic chalk as woll as filled burrows are found in the underlying marl. Jower beds of the silty marl crop out on meanders of both branches of the creek just above their junction. Farther downstream the hard, norl-glauconitic chalk and jis transition into highly calcarcous marl are well shown in a series of outcrops.

The uppermosl silty marl beds are exposed in a deep gully at locality 7 . Chalk may be found by shallow digging in the sides of the channel just above the head of tho gully. Lower beds of the Wolfe City crop out in roadside gullies at localities 8 , 9 , and 10. 
A steep-sided valley makes a deep reentrant into the chalk al locality 11. A ledge of the basal chalk, glauconitic in its lower part, forms a small waterfall (at times of run-off) near the head of this valley. Silty marl is washed up from the pool below and crops out in the banks farther down the channel.

A better, although small, exposure of the actual contact may be found in the gully on the east side of the road at locality 12. The basal glauconitic chalk appears again at a small spring east of the road on the southeast side of this same valley, while the uppermost silty marl beds crop out in a cut bank farther downslream west of the road. Where this same road crosses the next small tributary toward the south (locality 13), hard white chalk is prominent in the road ditches on both sides of the valley, but the basal beds are not exposed. This is apparently, the locality mentioned by Ellisor and Teagle as about 2 miles north of Marlin.

From this point southward the Pecan Gap-Wolfe. City contact is very difficult to follow because it is almost everywhere concealed by the terraces and flood plain of Brazos River. The difficulty is increased by lithologic changes within the Pecan Gap. It appears that the highly calcareous marl found on the experimental watershed becomes slightly silty in the vicinity of Marlin, although much less so than the underlying Wolfe City beds. Also the higher chalk beds become harder, thicker, and more resistant to crosion and consequenlly more prominent in outcrop:

From locality 12 southward the contact apparently follows the east side of the same small stream valley to the edge of the Brazos bottoms, where il turns southeastward for a short distance along the edge of the hills.. Its presence is indicated only. by seeps, which in view of the presence of some gravelly alluvium are somewhat uncertain criteria. In the toltom of a longabandoned gravel excavation at locality 14 , crawfish have brought up very silty marl of the Wolfe City, and similar material occurs in a poor oulcrop on the west side of the next valley to the east (locality 15). Chalk appears at locality 16 on the east side of this same valley and highly calcareous marl at 17 in the next. small valley eastward. It seems therefore that the con- tact disappears beneath the alluvium of the botlom-lands in this vicinity.

Hayd, white chalk, becoming blue gray at shallow depth, crops out in the bed of Brazos River at the lower of two sharp bends just below the mouth of Perry Creck (loc. 18, Pl. II). Hole 1020, a pit dug ir the chalk at this location, penetrated the Pecarı Gap-Wolfe City conlact at depth 14 feet (elevation approximately 307). Downstream from. this point highly calcareous marl crops out in the river bed al intervals for about a mile, becoming harder and chalkier again at the tradilional "Falls of the Brazos" (loc. 19, Pl. II), where the ford is located.

It would appear therefore that most of the other chalk outcrops in this region mentioned in the literature belong considerably above the base of the Pecan Gap member and are stratigraphically higher than the principal chalk bed crossing the experimental watershed. Assuming a strike of N. $20^{\circ}$ E. and a dip of 80 feet per mile, and in the absence of any evidence of repetition of strata, the outcrop (loc. 20 , Pl. II; elevation 479 to 485 ) described by Ellisor and Teagle on Big Creek just south of the Riesel-Mart road would represent: a stratum just a few feet bigher than the hard chalk on the experimental area, or between 11 and 19 feet above the base of the Pecan Gap. The chalk described by Dane and Stephenson on Big Creek just south of the McLennan-Falls County line (locality 21, elevation approximately 463) would be about 140 fcet above the base of this member. In hole 1.010 (Iocality 22) the "upper chalk" of the southeastern part of the experimental area was encountered from elevation 434 to 447 , which is 116 to 129 fcet above the base of tho Pecan Gap.

Ellisor and Teagle select as the type locality for the Diploschiza cretacea zone of the Pecan Gap member an outcrop at locality 23, about 1 mile east of Lamar School (called Harmony Hill on some older maps). Here the rock is not very hard and corresponds more nearly to what the present authors have called "inter. mediate" between chalk and marl on the experimental area. At approximale elevalion 416 , this outcrop would be about 90 feet above the base of the Pecan Gap.

Dane and Stephenson's type locality for the Marlin chalk is on the bluffs facing the 
Brazos bottoms 0.4 and 0.9 mile south of the court-house at Marlin. Between 30 and 40 feet of chalk are exposed in a deep, branching gully near the bend of MeCullough Slough (loc. 24, Pl. II). A thin shell breccia about 3 feet above the lowest chalk exposed is at approximate elevation 341, which would be aboul 112 feet above the base of the Pecan Gap. The chalk at the "Falls of the Brazos," about 2 miles farther south, should be a litlle lower in the section because of its slightly lower elevation.

It thus appears that in this vicinity the Pecan Gap member consists of the following:

(a) A continuous zone of hard chalk at the base, 10 to 20 feet thick, resting with slight unconformity on the silty marl of the Wolfe City member. The lowest foot or so of chalk is often softer, contains a little silt, and is everywhere glauconitic. This is transitional upward into:

(b) Nincty or more feet of highly cal. careous marl, almost entirely free from detectable silt except in the vicinity of Marlin.

(c) A discontinuous zone of chalk, softer than the lower chalk, from 10 to 40 feet thick, and probably not everywhere at exactly the same stratjgraphic horizon. This is transitional into the highly calcareous marl both above and below and probably laterally as well.

(d) Additional highly caIcareous marl, of undetermined thickness, extending to an undefined contact with the "Marlbrook. marl" or with the Navarro group.

Ellisor and Teagle divide the Pecan. Gap into three faunal zones, chiefly on the basis of the foraminifera, and state that the lowest zone is absent in the latitude of McLennan County and that in this. region the middle or Diploschiza cretacea zone forms the base of the nnember. 'They mention that in Falls County the chalk outcrop has a more or less uniform width of 1.5 to 2 miles, and that in that outcrop Diplosehiza cretacea is. found near the top of the chalk and Pycnodonte vesicularis toward the base.

Except for the determinations on samples from holes 1010 and 1011 , given in the appendix, no micropaleontological work: has been done in connection with the present work, and nothing is known of the distribu- tion of foraminifera in tho lilhologic subdivisions above proposed. Howcver, in all the outrrops and borings studied on the experimental aтеa, only one or two of the fossils found might possibly have been Diploschiza cretacea minor. This species is present aboundantly in the outcrops south of Marlin (locality 24) and sparingly in the outcrops on Big Creek near Mart (locality 20) and also near the county line (locality 21). It may also be found in the outcrops on Brushy and Little Brushy creeks just below hole 1010.

Pycnodonte vesicularis has rarely been found in place by the present authors, but it is present in the terrace alluvium immediately overlying the chalk and marl along Big Creek near the county line (locality 21). A large flat variety similar to thiat figured by Dane $(1929$, PI. XVIII, p. 94) was found here. $\Lambda$ smooth convex variety similar to that shown in Dane's Plate XI, page $66,{ }^{10}$ is common in the banks and channels of both Brushy and Little Brushy creeks in the vicinity of hole 1010. Specimens with various degrees of wing development were also found at this locality. Shells of Pycnodonte are also common in the channel of the tributary which enters Brushy Creek from the west just below gaging station J (Pl. I). On the main stream they were not found north of localily 25 (Pl. II). This is just below the mouth of another tributary from the west draining a hill on which the upper chalk stratum occurs.

Shells of Pyonodonte were also found at an outcrop of highly calcareous marl in a gully directly in front of St. Paul's School (loc. 26, PI. II). This is at approximate elevation 439 and should be about 105 feet above the base of the Pecan Gap.

No Pycnodonte shells have been found in any outcrops or borings in the lower chalk, that is, the principal chalk stratum on the experimental watershed, nor in any of the strcam channels where they cat through these beds:

It therefore secms that Diploschiza cretacea minor is common in the upper chalk but very rarc below this zone. This is in accord with Stephenson's stalement (1934, p. 275) " that "this variety is confined to a zone which in general is 30 or 40 feet thick,

\footnotetext{
${ }^{10}$ Thiy is dercribed as Gryphaeg convexa (Say) by Ste. I lı)пно $(1937$, p. 1M).
} 
and probably does not exceed a thickness of 100 feet." Pycnodonte vesicularis is also common in the upper chalk but absent below a horizon at least 75 feet above the base of the Pecan Gap member in this vicinity. On the other hand, Exogyra ponderosa, comimon in the lower chalk, is rare in the upper, whereas Inocerami are common to both. Baculites are abundant at the very base of the lower chalk but have not been observed in the upper by the present authors. The single specimen of Echinocorys cf. E. texana (Cragin) $^{\text {ti }}$ found by the authors was in place in the upper chalk at locality 21 on Big Creek.

That the two chalks are not merely the result of repetition of strata due to faulting is well demonstrated by the log of hole 1010 (see appendix). Minor faults do occur on the experimental watershed, but thcir displacement must be only a few feet. A group of faults apparently of somewhat greater magnitude occurs in the chalk cropping out in Brazos River near hole 1020. The most prominent ones are indicated in Plate IJ. The slickensides sug. gest that they are downthrown on their east side, but the evidence is not very clear. $\Lambda$ downthrow on the west mighl be expected to cause a repetition of the Wolfe City beds in the river, but as already mentioned this does not occur. The displacement of the faults cannot be very great, because the straligraphic intervals between the base of the Pecan Gap member and the outcrops of tho upper chalk, discussed above, which were calculated without considering any displacement, agree within the error of the elevations, which were determined with un aneroid barometer.

It would seem probable that both the upper and the lower chalk zones should be present also in that part of Falls Coundy soulhwest of Brazos River. The broadening of the Pecan Gap belt of outcrop shown in that region on the geologic map of 'Texas appears too great to be morely the result of the repetition by faulting of the com. paratively narrow belt shown north of the river, which, as is evident from the foregoing discussion, represents little more than the upper chalk zone.

At the lime this paper was originally prepared (1942) no work had been donc by the authors south of the Brazos, bul. brief

בFisurat by Dane: (1929, PI. XV, p. 86). explorations by the senior author in the aulumn of 1944, showed that both the lower and upper chalk zones are present in the region southeast of Lott. The Pecan GapWolfe City contact was found at a small outcrop in a roadside gully $2 \frac{1}{4}$ miles east-southeast from the railroad station at Lott. Here hard, weathered, glauconitic chalk overlics the typical Wolfe City silty marl. As al olher localities, the uppermost márl contains lenses of chalk.

Two miles cast by south from this locality, hard white chalk is extensivcly exposed in the channels and hanks of Pool Creek and Bell Branch, both above and below their junction. The writer (Blank) found Diploschiza fairly common here, as reported by Ellisor and Tcaglc. A few Pycnodonte were also found but no $E x$ ogyra ponderosa. These outcrops evidently represent the upper chalk.

On the Westphalia-Lott highway $1 \%$ miles northeast by north from Westphalia, weathered chalk crops out in the road ditches, and typical Wolfe City silty marl appears in a deep gully a few hundred yards northeast of and down-bill from the chalk. The actual contact was not found.

Three and one-quarter miles east-northeast from Westphalia, hard white chalk crops out in a gully at a road bridge over Pond Creek. Exogyra ponderosa shells were found in this chalk, and it apparently helongs to the lower zone.

$A_{s}$ in the vicinity of Marlin, in this region the highly calcareous marl between the two chalks appears to contain appreciable silt, which renders its identification difficult in isolated outcrops. Tracing of the Pecan Gap-Wolfe City boundary and of the two chalk zones in this part of Falls County is also impeded by the Brazos River terraces and by faulting, but there seems little doubt that both upper and lower chalks are well represented.

The present aulbors have not completely traced the chalk - silty marl contact northcastward from the area shown in Platc II, but numcrous observations between Big Creck and Navasota River indicate that in this region the Pecan Gap-Wolfe City boundary follows fairly closely the posilion shown on the geologic map of Texas.

Since this paper was originally prepared (1942), Rouse (1944) has described the Pecan Gap-Wolfe City contact in north- 
east 'Texas. In that region he found Exogyra ponderosa abundant in the Wolfe Cily but not in the Pecan Gep. He states that from Collin County to Red River County, where the chalk disappears, the basal zone of the Pecan Gap is characterized by black phosphatic pebbles, phos. phatized Baculites and other fossils, and commonly glauconite. The present authors have not found the phosphate pebbles at this contact in McLennan and Falls counties. However, Rouse's observation that "at all good exposures of the contact, chalkfilled borings extend down into the underlying Wolfe City formation" applies equally well to the exposures herein described.

\section{REFERENCES}

Abxins, W. S. (1933) The Mesozoic systems in Texas, in The geology of Texas, Vol. I, Stratigraphy: Univ. Texas Bull. 3232, Aug. 22, 1932 , pp. $239-519$.

Geology and Arick, M. B. (1930) Geology of Bell County, Texas: Univ. Texas Bull. 3016, 92 pp.

BAInd, R. W., JENKINS, D. S., and others (1942) Hydrologic data: Blacklands Experimental Watershed, Waco, Texas, 1987-1939: U. S. Dept. Agr. Hydrologic Bull. 2, I97 pp.

Bayn, R. W., LAurxizeN, C. W., and others (1942) The agriculture, soils, geology, and topography of the Blacklands Experimental Watershed, Waco, Texas: U.S. Dept. Agr. Hydrologic Bull. 5, $38 \mathrm{pp}$.

DANE, C. H. (1929) Uppor Cretaceous formations of southwestern Arkansas: Arkansas Geol. Surv, Bull, 1, $2 \mathrm{~L} 5 \mathrm{pp}$.

(1928) Noles on, and STEPHENSON, In W. tions in enst-central lexas: Bull. Amer. Pctr. Gcol, vol. 12, pp. 41-58.

Darton, N. H., Stephenson, L. W., and Gardner, JuLIA (1937) Geologic map of Texus, U.S. Geol. Survey.

Deuseren, AlEXANDER (1924) Geology of the Coastal Plain of Texas west of Brazos River: U. S. Geol. Survey Prof. Paper 126, 139 pp.

Ellisor, A. C., and Tragle, JoHn (1934). Correlation of Pecan Gap chalk in Texas: Bull. Amer. Assoc. Petr. Gcol., vol. 18, pp. 1506-1536.

Hit., R. T. (1901) Geography and geology of the Black and Grand Prairies, Texas: U.S. Geol. . Survey 2lst Ann. Rept., pt. 7, pp. 1-666.
Hulemranb, W. F. (1919) The analysis of silicate and carbonate rocks: U.S. Geol, Surrey Bull. $700,285 \mathrm{pp}$.

Ireland, II. A., Sharpe, C. F. S., and Eargle, D. H. (1939) Principles of gully erosion in the Piedmont of Sonth Carolina: U. S. Dept. Agr. Tech. Bull. 633, $142 \mathrm{pp}$.

Milver, H. B. (1940) Sedimentary petrography, .3d ed., Thos. Murby \& Co., London, 666 pp.

Otmsteai, L. B., Alexander, L. T., and Middle. ToN, H. E. (1930) A pipette method of mechanical analysis of soils based on improved dispersion procedure: U. S. Dept. Agr. Tech. Bull. $170,22 \mathrm{pD}$.

Plummer, F. B. (1933) Cenozoic systems in 'Texas, in The geology of T'exas, Vol. I, Stratigraphy: Univ. Texas Bull. 3232, Aug. 22, 1932, pp. $519-818$.

Potter, W. D., and Blank, H. R. (1939) BlackIands Experimental Watershed ground-water graphs, 1936-1937: U. S. Dept. Agr. SCS-TP-2A.

Rouse, J. T. (1944) Correlation of the Pecan Gap, Wolle City, and Annona formations in east Texas: Bull. Amer. Assoc. Petr. Geol., vol. 28, pp. 522-530.

SAYRE, A. N. (1936) Geology and ground-water resoures of Uvalde and Medina countics, 'Texas: U. S. Geol. Survey Waler-Supply Paper $678,146 \mathrm{pp}$.

Skitakes, E. H., Aderins, W. S., and Pllimmer, F. B. (1933) 'The geology of Texas, Vol. I, Stratigraphy: Univ. T'exas Bull. 3232, Aug. 22, 1932,7007 pp.

SHARPE, C. F. S. (1938) Landslides and related phenomena, Columbia Univ. Press, New York, 137 PP.

Siraw, W. M. (1931) Determination of $\mathrm{CO}_{2}$ in soil carbonates-A modification of the official method: Jour. Assoc. Offe, Agr. Chemists, yol. 14, pp. 283-292.

STENzEL, H. B. (T938) The geology of Lcon County, Texas: Univ. Texas Bull. 3818, 295 pp.

Sirephenson, L. W. (1918) Contributions to the geology of northeastern Texs and southern Oklahoma: U. S.' Geol. Survey Prof. Paper 120-H, pp. 129-163.

Upper Cretaccous series of Texos: Assoc. Petr. Geol., vol. 13, pp. 1323-1334.

- (1934) The genus Diploschiza from the Upper Cretaceous of Alabama and Texas: Jour. Paleont., vol. 8, pp. 273-280.

(1937) Stratigraphic relations of the Austin, 'laylor, and equivalent formations in 'Texas: U. $S$. Geol. Survey Prof. Paper 186-G, pp. 133-146. 


\section{APPENDIX}

\section{Well Data}

\section{HOLE 694}

Location.-Falls County. Gregorio Basquez survey; about $3 / 8$ mile northeast by east from Trinity Lutheran Church; 45 feel from southeast and 900 feet from northeast lines of Governmenl-owned land. Landowner, U. S. Government (formerly A. Kuehl). Elevation of ground surfacc, 506.8 feet; total depth, 54.6 feet. Diameter, 13 inches.

Method and disposition.-Hand auger and hand-operated spudding bil with derrick. Drilling begun, June I, 1939; completed, December 8, 1939. Driller, W.P.A. and C.C.C. crews. Uppermost 17.9 feet cased with $12 \frac{1}{4}$-inch pipe; backfilled to 40.3 feet total depth and converted to observalion well.

Remarks.-Large water supply for shallow wells of this size in this vicinity, but water carries about 6,000 p.p.m. total solids by rough analysis.

\section{$\log$}

(from field log, observations, and samples)

Recent alluvirum-

Top soil (under Bermuda grass sod) -black, sticky, contains streaks and patches of fine (visihle) sand and a fow pebbles

Depth Thickness

Feet Feet

Terrace all uviurn..

Soil-black, contains very little sand, dry below 5 feet

Sub-soil-brownish gray to yellow; conlains visible sand, fine gravel, and a few pebbles up to 1 inch in dimmeler; also soft white $\mathrm{CaCO}_{3}$ concretions

$5.8 \quad 3$

Decayed alluvial marl-yellowish gray with rusty and black spots and streaks; gritly on chewing; pebbles up to 2 inches long; lumps of undccayed marl.

Pecan Gap-

Lower highly calcareous marl-

Decayed residual marl-brownish gray with rusty spots and numerous joints with white decay; very slight grittiness on chewing

Sound residual marl--.brownish gray, less rusty and more compact than preceding, conchroidal fracture, very faintly ]aminated...

A little water at 12.9 feet after hole stood six days. Easily removed and did not reappear.

Marl-alternating streaks or layers of brownish gray and blue gray, with blue gray gradually becoming dominant with increasing depth; dry

Marl-blue gray, uniform, hard, and dry; faintly laminated; poor conchoidal fracture; eftervesces readily with dilute acid; slight grittiness between teeth disappears on long chewing; a lew shell frugments

Water at 19.2 feet.

"Intcrmediate" between marl and chalk-blue gray, harder than preceding; brcaks with snap

Additional water at 25 feet.

Much additional water at 27.2 feet; bailing necessary; apparently no additional water below 29.3 feet.

Marl-greenish gray; hard but softer than the proceding "intermediate" material; apparently dry

"Internediate", similar to that above 29.3 feet-blue gray, hard, apparently dry

、 Lower chalk-

Chalk-hlue gray, very hard; breaks with snap, fracture hackly, not conchoidal; texture coarse for chalk; numerous foraminifera and spines visible under hand lens; uniform, no lamination visible; apparently dry; occasional lossils, including one $31 / 2$. inch Inoceramus. 
Chalk--blite gray; very hard; contains streaks, lenses, and patches Depth Thickness of greenish-gray, slightly softer, chalky marl; both chalk and marl contain invisible silt detectable on chewing; all becones harder and chalkier with increasing depth but retains appearance of a breccia; abundart foraminifera and spines but few

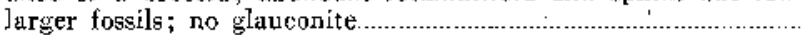

Chalk - marly cbalk breccia, similar to preceding but more uniformly hard; contains tiny dark green spots of glauconite, increasing in amount with depth; also some pyrite, some invisible silt

Wolfe City-

Silty marl ...

(Chalk just above contact contains broken pieces of silty marl. Silly marl just below contact contains rounded lumps and lenses (compressed burrows?) of chalk.)

Silty marl-dark greenish gray (nearly black when wet), much softer than the chalk; shrinks, cracks, and hardens on drying; flaky, contains, much invisible silt, casily felt on chewing; no free water; narl very uniform after first foot below chalk; no lossils except a few decayed shell fragments.

\section{HOLE 1000}

Location.-Falls County. Gregorio Basquez survey; on west bank of Brushy Creek about 10 feet south of bridge carrying County Road 339; about 21/4 miles westnorthwest of Otto. Landowner, county right-of-way. Elevation of ground surface, 454 feet; tolal depth, 1.7.4 fect. Diameter, 12 inches approximately.

Method and disposition,--Hand auger and bars. Drilling begun, March 12, 1937; completed, $A$ pril 14, 1937. Driller, W.P.A. crew. Cased with 6-inch pipe and converted to observation well.

Remarks.-Possibly all the strata below the alluvium in this holc should be included in the upper chalk if they are to be correlated with the interpretation of Hole 1010 .

\section{Log}

(from field $\log$ and samples)

Recent and terrace alluvium-

Sail-black, sarily and sticky.

Pepth Thickness

Ground water at 7 feet 4 inches.

Feet Feet

Marl--gray and yellow, with a few small rusiy streaks; crumbly; contains much sand and numerous large and small pebbles.

\section{Pecan Gap-}

Upper highly calcareous marl?-

Marl-brownish gray, with gray streaks and rusty stains; hard for marl; no sand or silt detectable on chewing; apparently dry

Upper chalk-

Hard marl or "intermediate" between marl and chalk-bluc gray breaks with suap

Marl-brownish gray, with gray and rusty streaks; much softer than preccding

"Intermediate"-blue gray; same as 11 to 12.7 leet

Chalk-..tylue gray; hard; no silt on chewing.

Marl-yellow, with dark brown and rusty streaks; s]ightly moist

Chalk-bluc sray; same as 13.9 to 14.5 feet.

$\begin{array}{ll}9.0 & 9.0 \\ & - \\ 9.8 & 0.8\end{array}$

\section{HOLE 1010}

Location.-‥Falls County. L. F. Reed survey; about 35 feet north of County Road 339 and about 35 feet east of Little Brushy Creek; ahout 21/4 miles west-northwest of Otto. Landowner, Mrs. F. B. Moore. Elevation of ground surface, 463.2 feel; total depth, 160.3 feet. Diameter, 13 inches to 24.9 feet; 8 inches from 24.9 feet to bottom. 
Method and disposition.-Hand auger to 24.9 feet; earth socket (excavator) on cable tool rig (power operated) from 24.9 feet to bottom. Drilling begun, November 8, 1937; completed December 10, 1937. Driller, W.P.A. crew (by hand); B. J. Thornpson, Waco (by machine). Uppermost 24.8 feet cased with 8-inch pipe; converted to observation well.

Remarks.-No water in hole at conclusion of drilling; about 0.7 foot of water observed January 3, 1938; water rose very slowly but continuously to depth 117.86 feet below ground surface at last observation, July 18, 1940; seepage apparently comes from upper part of hole.

$$
\log
$$

(from field log, observations, and sainples)

Recent aIluvium?-

Top soil-dark brown; contains manure and many small hard $\mathrm{CaCO}$ concretions

\section{Terrace alluvium-}

Soil-black, less friable than preceding; contains a little sand and a fcw pebbles; also hard $\mathrm{CaCO}_{3}$ concretions and soft black concretions

\section{Depth Thickness \\ Feet Feet}

Marl-gray, with a few risty spots and white concretions; very sandy; numerous pebbles, especially close to base.

A little water in hole after standing over night; casily rcmoved.

Pecan Gap-

Upper highly calcareous marl-

Murl-yellow for first foot, then gray to brownish gray; hard for marl; contains no sand

Uppex chalk-

Soft chalk-blue gray; contains no sand

MarI-rusty, soft, 'moist.

Soft chalk-b]ue gray; contains no sand; one or two thin streaks of rusty mari

Marl-solt, moist

Chalk-blue gray, hard, compact, fine grained.

Marl-bluc gray, soft, moist..

Chalk-blue gray, hard, compact, fine grained

No record

Chalk-light biue, moderately hard, dry.

Lower highly calcareous marl-

Marl-light blue, a few shell fragments ....

Chalk-light blue, moderately hard

Marl-light blue.

Hard marl or "intermediate" between marl and chalk-light blue, dry....

MarI-blue gray; softer than preceding run but hard for matl; dry.......

MarI-hlue gray, similar to preceding but slightly softer; unctuous, slightly moist, traces of fossils

Mari $\longrightarrow$ Imilar to preceding but a little harder, dry

Hard marl ur "intermediate"-blue irray, dry.

Marl-blue gray, similar to preceding but a little softer; very uniform, no grit on chewing, slightly unctuous, dry; traces of fossils here and there

Marl-greenish gray, congidcrably softcr than the preceding, slightly moist .

Marl-blue gray, hard, similar to 56.6 to 75.8 feet; dry.

Marl-agreenish gray, softer, a few decayed shell fragments, slightly moist

Marl-bluce gray, gradually becoming harder, dry; a few fossils, including Inoceramus, at 93 feet

Hard marl or "intermediate"--bIue gray, no grit on chewing, dry............

Hard marl or "intermediate"-similar to preceding but trace of grit on chewing; gradually becoming harder with depth; gencrally barren but a few fossil fragments at 116 and 118 feet; dry.

Jower chalk

Soft chalk-ight blue, harder than preceding, no grit on chewing, traces of fossils; dry...

"Internediate"-blue gray, a Iittle softer than chalk, no' fossils, dry 
Chalk-light blue, hard, no grit on chewing, slightly unctuous,

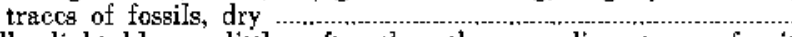

Chalk-light blue, a little softer than the preceding, trace of grit

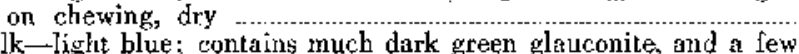

Chalk-light blue; contains much dark green gleuconite, and a 1
pieces of dark grayith-black marl; gritty on chewing, dry...

Wolfe Citypieces of dark grayith-black marl; gritty on chewing, dry.

Silty maxi-

Marl-dark grayish black, silty on chewing; contains white patches and streaks of glauconitic chalk; traces of fossils, dry.......

Marl-very dark blue gray; much fine silt on chewing but no visible sand; contains light gray spota and angular arcas which are

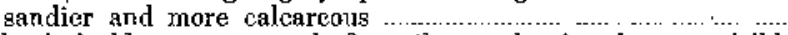

Marl-dark blue gray; much fine silt on chewing bnt no visible sand; compact and tough, not brittle; uniform, a lew decayed fossils, dry

$\begin{array}{cc}\begin{array}{c}\text { Depth } \\ \text { Feet }\end{array} & \begin{array}{c}\text { Thickness } \\ \text { Feet }\end{array} \\ 141.2 & 11.7 \\ 144.5 & 3.3 \\ 145.5 & 1.0 \\ 147.3 & 1.8 \\ 150.5 & 3.2\end{array}$

160.3 T.D. $\quad 9.8$

\section{MYCROSCOPIC FOSSILS}

Determinations by laboratory of Humble Oil \& Refining Company, Houston, Texas; under direction of F. W. Rolshausen. Samples examined were selected from material obtained by means of a hand auger, a pipe driven into the bottom of the hole, or an earth socket (excavator) churned on a cablc tool drilling machine.

Fecan Gap- -

Light-buff and white chalky marl

Frandicularia sp.

Globigerina cretarea

Planulina taylorensis

Anomalina henbesti

Globorotalia micheliniana

Globotruncana arca

Gyroilina depressa

Clavulina triangulata

Light bluish-gray clalky mar]. Same fossils as preceding plus Bulimina sp. und Cassidulina sp. (2 samples). ............. $22^{\prime} 6^{\prime \prime} ; \quad 27^{\prime} 9^{\prime \prime}-28^{\prime} 9^{\prime \prime}$

Blurish-erry marl. Same fossils as preceding plus Marginulina sp.................. $\quad 43^{\prime} 11^{\prime \prime}-4^{\prime} 6^{\prime} 4^{\prime \prime}$

Light bluish-gray chalky marl. Same fossils as prcceding plus Kyphopyxa christneri.

Rohulus sp.

Nodosaria sp.

Bolivinoides decorata

Guembelina ghobifera

Textularia sp.

Heterostomella americana

Dorothia bulletta

Bluish-gray chalky marl; same fossils as preceding

(2 samples)

Jight gray marly chalk; same fossils as precedingWolfe Cily-

Mediun gray shaly mar

$\begin{array}{ll}\text { Globigerina cretacea } & \text { Ammobaculites sp. } \\ \text { Planilina taylorensis } & \text { Globotruncana arca }\end{array}$

Rohrilus sp.

Ciavulina triangulata

Trochammina sp.

Medium gray shaly marl. Same fassils as preceding plus

Robulas taylorensis and Nodosaria sp.

Deptla

$11^{\prime} 9^{\prime \prime}-12^{\prime} 2^{\prime \prime}$

$79^{\prime} 5^{\prime \prime}-81^{\prime}$

$100^{\prime} 5^{\prime \prime}-102^{\prime} 2^{\prime \prime} ; 132^{\prime} 10^{\prime \prime}-133^{\prime} 9^{\prime \prime}$

$143^{\prime} 6^{\prime \prime}-1444^{\prime} 10^{\prime \prime}$

$116^{\prime} 2^{\prime \prime}-147^{\prime} 4^{\prime \prime}$

HOLE TO11

Location.-Falls County. H. Fanthorp survey; on southwest side of County Road $328 \mathrm{~A}$, about 500 feet southeast along this road from Gaging Station $\mathrm{Y}$ and about 3,300 feet northwest along this road lrom Cuunty Road 337; about 2\% miles east of Riesel. Landowner, U. S. Government (formerly Otto Stieg). Elevation of ground surface, 526.4 feet; total depth 201 feet. Diamcter, 14 inches to 32.1 feel; 8 inches from 32.1 feel to bottom.

Method and disposition.-Hand anger to 33.3 feet; earth socket (excavator) on cable tool rig (power operated) from 33.3 feet to bottom. Drilling begun, October 19, 1937; completed, December 2, 1937. Driller, W.P.A. crew (by hand); B. J. Thompson, Waco (by machine). Cased with 8-inch pipe to deplh 32.1 feet; 6-inch pipe from surface to total depth, with perforations in the sandy marl from depth 
93.7 to 103 feel and from 115.7 feet to bottom; water from chalk scaled off; converled to obscrvation well.

Remarks.-Well bailed dry after casing January 3, 1938; water rose continuously until it reached equilibrium at 9.04 feet below ground level on March 28, 1939 ; water very sally; about 12,000 p.p.m. total solids.

(from field log; observations, and samples)

Pexan Gisp-

Residual suil-.

Top soil--bluck, sticky

Sub-soil-dark gray to ]ight gray, dry and powdery.

I.ower bighly culcureons marl-

Decaycd marl ot "intermediate" between marl and chalk--crumbly, a few shell fragments

Lower chalk.-

"Intermediate" hetween marl and chalk-light tan, whiter on dryingr;

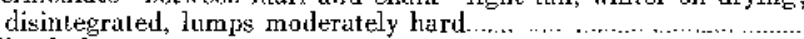

Chalk-light tan, disintegrated, lumps hard; harder and more brittle with incrcasing depth; moist

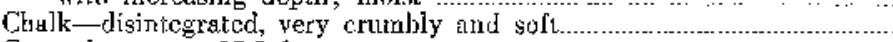

Ground water at 15.5 feet.

Chilk -...Tight tan, hard and brittle, moist.

Chalk - lisht tan with rusty and gray patches, disintcgrated, soft, wct ...

Wolle City-..-

Silty marl

Silty marl-brown, with rusty and light gray streaks; invisible silt throughout, detected on chewing, moist

Silty marl-chiefly brown, with blueblack streaks and lenses; the blue black generally more compact and less moist; sand jist visithe at a few places, occasional strcaks of crystalline gypsum

Silty marl-bine black with some rusty streaks

Silty marl-blue gray; much silt throughout, barely visible to eye but easily to hand lens; no fossils, dry...

Silty marl-blue gray, similar to preccding but contains a few small. shells; silt a little coarser toward bottom

Sandy marl-

Sandy marl-blue gray, rich in defnitely visible sund; contains a few small pieces of hard, bluc, calcarcous sandstone; also a fow

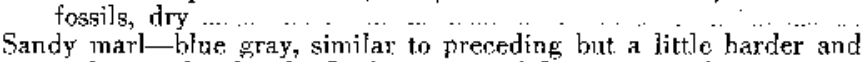
richer in fossils, chielly fragments of Inoceramus, dry.

Sandy marl-- blue cray, plainly visible sand throughout, also numerous thin laminae of very fine white sand; lenses of hard calcarcous sandstone up to $\mathbf{J}$ inch thick; slightly moist at about 95 feet and at about 700 feet; elsewhere dry; fossils scarce.

Sandy marl...blue gray, softer than the preceding, very sandy, visib]e sand throughout, also in distinct laminae and pockets; very little hard sandstone; porous, moist at many places, no tossils, eftervesecs slawly with dilute TICl.

Sandy marl-blue gray, very sandy; generaljy similar to prereding run but contains numerous pieces of calcareous sandstore in various slages of consolidation; no fossils, slightly noist................

Sandy mari-bluc gray, alternating sandy and claycy laminac, this material alternating on a larger scale with harder, finer ${ }^{12}$ beds up to 2 inches thick; very litt]e hard samdstone; numerous decayed shell fragments, dry

Sundy mal -...blue gray; laminated like the preceding, but laminae are more lenticular and contain "knots" of calcareous sandstonc, structure reminiscent of sone mica schist; fossils scarce, dry..

Sandy marl-blue gray, very sandy, irregular laminae and porkets of coarser gray sand, a few small pieces of hard sandstone; fossils scarce, moist in places, tastes of gypsum.
Depth Thickness
Feet

14.5

15.7

6.0

17.1

18.3

1.4

1.2

113.6

153.4

10Th: termo coarser and finer as uned in this descriptine sre relative; atiuslly none of the sard described $j 8$ any

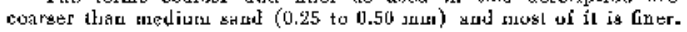




\begin{tabular}{|c|c|c|}
\hline & $\begin{array}{l}\text { Depth } \\
\text { Feet }\end{array}$ & $\begin{array}{c}\text { Thickness } \\
\text { Feet }\end{array}$ \\
\hline $\begin{array}{l}\text { Sandy marl-blue gray, finer and harder than preceding run, a } \\
\text { fcw pieces of calcarcous sandstonc of various degrecs of con- } \\
\text { solidation, dry }\end{array}$ & 198.4 & 2.6 \\
\hline $\begin{array}{l}\text { Sandy marl-blue gray; irregular laminae, with lenses of coarser } \\
\text { sand und tiny kinots of hard culcureous sundstone; structure like } \\
\text { mice srhist, very shightly moist }\end{array}$ & $201.0 \mathrm{~T}$. & 2.6 \\
\hline
\end{tabular}

Microscoric FossiLs

Determinations by laboratory of THumble Oi] \& Refining Company, Houston, Texas, under direction of F. W. Rolshausen. Samples examined were selected from material obtained by means of a hand auger, a pipe driven into the botton of the hole, or an carth socket (exavator) chumed on a cable tool drilling machine.

Pecan Gap-

White and huff marly chalk (5 sampilcs)

Globigerina cretacea

Frondicularia sp.

Kyphojyxa christneri

Planulina taylorcnsis

Anomaling henbesti

Globorotalia micheliniana

Nodosaria affinis

Clavolina triangulata

Clobotruncana isca

White ard buff chalky manl with a trace of glauconite included; same fossils as above

As preceding but with morc glanconite; same fossils.
As preceding but with brown mart; same fossils

Pecan Gap-Wolle Cily Iransition zono-

Bufl marl, trace of glauconite; conlains both Pecan (Fap and Wolfo City tossils which arc considered in place (2 samples)

Globorotalia mícheliniana

Bulimina ap.

Plamulina taylorensis

Trochaminina sp.

Globotruncinad alrea

Wolfe City-

Pullenia sp.
Robulus laylorensis
Bolivinoides decosata

Nodosaria vertebralis

Gyroidina sp.

Fish tccth

Haplophragmoides sp.

Depth

Buff and bJuish-gray shaly mar], trace of glauconite and sand included. Planulina taylorensis

Bulimina sp.

Nodosaria sp.

Globotruncana arca

Guembelina glohifera

Robulus taylorensio

Robul.us sp.

Haplophragrmoides sp.

Verncuilina sp.

Bluish-gray and buff shaly marl, trace of glauconitc. Same fossils as preseding plus Clatudina triangulata and ostracodes

Bluish-gray marly shale, trace of sand (2 samples) Ammobaculites sp.

ClavuTina triaugutata

Gaudryina sp.

Globiscerina cretacea

Gucmbelina slobifera

Bigenerina sp.

Nodosaria sp.

Globotruncatia area

Robulus tay]orensis

Ostracodes

Chocolate-colored and bluigh-gray shaly marl, trace of selenite and sand.

Samo fossils as preceding plus Nodosaria affinis and Saracenoria sp.

Same as proceding with a few swall sandstonc fragments included; same fossils as preceding

Bluish-gray marly thate, trace of sand. Same fossils as preceding plus toxostoma sp.

Hobulus sp.

Kyphopyxa christneri

II uplophrapmoides $\mathrm{sp}$.

PJanulina taylorensis

Anomalina henbesti

Gyroidina sp.

Gyroidina

Sarne as preceding but with morc sand; same fossils (2 samples)

Graly shaly marl, trace of sand; same fossils (4 samples). Samp]e from $57^{\prime} 3^{\prime \prime}-59^{\prime 2} 2^{\prime \prime}$ also contains Flabellammina sp. 
Gray sandy marl; fewer fossils (7

Same as preceding but not quite as sandy; same fossils (4 samples)
Deptht

$64^{\prime} 0^{\prime \prime}-65^{\prime} 9^{\prime \prime} ; \quad 65^{\prime} 9^{\prime \prime}-67^{\prime} 6^{\prime \prime} ; \quad 68^{\prime} 8^{\prime \prime}-70^{\prime} 6^{\prime \prime}$; $72^{\prime} 3^{\prime \prime}-73^{\prime} 8^{\prime \prime} ; 75^{\prime} 4^{\prime \prime}-77^{\prime} 3^{\prime \prime} ; 79^{\prime} 1^{\prime \prime}-80^{\prime} 7^{\prime \prime}$; $82^{\prime} 0^{\prime \prime}-83^{\prime} 6^{\prime \prime}$ $84^{\prime} 10^{\prime \prime}-86^{\prime} 4^{\prime \prime} ; \quad 88^{\prime} 4^{\prime \prime}-90^{\prime} 0^{\prime \prime} ; \quad 91^{\prime} 8^{\prime \prime}-93^{\prime} 7^{\prime \prime} ;$ $95^{\prime} 4^{\prime \prime}-96^{\prime} 9^{\prime \prime}$

$98^{\prime} 4^{\prime \prime}-99^{\prime} 7 \prime \prime$ Gray sandy marl with small sandstone and limcstone nodules included; same fossils as preceding...

$10 \mathrm{l}^{\prime} 1^{\prime \prime}-102^{\prime \prime} 8^{\prime \prime} ; 103^{\prime} 10^{\prime \prime}-104 \mathrm{H}^{\prime \prime}$

Gray slightly sandy marl; same fossils (2 samples)

Same as preceding with possibly a little more sand; same fossils (14 samples) $106^{\prime} 7^{\prime \prime}-108^{\prime} 2^{\prime \prime} ; 118^{\prime} 2^{\prime \prime}-111^{\prime} 7^{\prime \prime} \xi^{\prime} 113^{\prime} 9^{\prime \prime}-116^{\prime} 1^{\prime \prime}$.

$118^{\prime} 5^{\prime \prime}-120^{\prime} 7^{\prime \prime} ; 122^{\prime} 6^{\prime \prime}-124^{\prime \prime} 5^{\prime \prime} ; 125^{\prime} 11^{\prime \prime}-127^{\prime} 10^{\prime \prime}$;

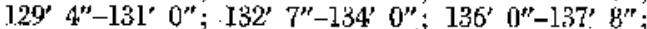

$139^{\prime} 7^{\prime \prime}-141^{\prime} 6^{\prime \prime} ; 143^{\prime} 3^{\prime \prime}-145^{\prime} 2 \prime \prime ; 147^{\prime \prime} 0^{\prime \prime}-147^{\prime} 7^{\prime \prime}$ $14,9^{\prime \prime}-\mathrm{I} 5 \mathrm{l}^{\prime} 0^{\prime \prime} ; 152^{\prime} 9^{\prime \prime}-154^{\prime} 0^{\prime \prime}$

Sume as preceding but with less sand; same fossils (7 samples).

$155^{\prime} 0^{\prime \prime}-156^{\prime} 8^{\prime \prime} ; 158^{\prime} 6^{\prime \prime}-160^{\prime} 3^{\prime \prime} ; \cdot 161^{\prime} 10^{\prime \prime}-163^{\prime} 6^{\prime \prime}$; $164^{\prime} 11^{\prime \prime}-166^{\prime} 10^{\prime \prime} ; 168^{\prime} 9^{\prime \prime}-170^{\prime} 4^{\prime \prime} ; 172^{\prime} 3^{\prime \prime}-173^{\prime} 10^{\prime \prime} ;$ $175^{\prime} 10^{\prime \prime}-177^{\prime} 7^{\prime \prime}$

Same as preceding but with more sand; same fossils (5 samples)

$179^{\prime} 3^{\prime \prime}-180^{\prime} 9^{\prime \prime} ; 182^{\prime} 5^{\prime \prime}-183^{\prime} 8^{\prime \prime} ; 185^{\prime} 2^{\prime \prime}-186^{\prime} 6^{\prime \prime}$ $\left.188^{\prime} 6^{\prime \prime}-190^{\prime} 6^{\prime \prime} ; 192^{\prime} 6^{\prime \prime}-194^{\prime}\right]^{\prime \prime}$

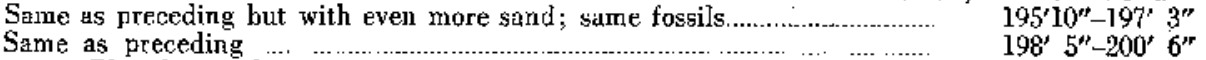

$\begin{array}{ll}\text { Planulina taylorensis } & \text { Gyroidina sp. } \\ \text { Robulus sp. } & \text { Nodosaria affinis } \\ \text { Robulus taylorensis } & \text { Globigerina eretucea } \\ \text { Clavulina triangulata } & \text { Ostracodes } \\ \text { Globotruncana arca } & \text { Oysters }\end{array}$

HOLE 1012

Location.-McLennan County. D. Sanchez survey; about 200 feet north of County Road 233, about 1/1/2 miles easl-northeast of business section of Riesel. Landowner, Ruby N. Turner (formerly C. B. Turner). Elevation of ground surfacc, 517.8 feet; total depth, 160.5 feet. Diameter, 111/2 inches to 20.2 feet; 8 inches from 20.2 feet to bottom.

Method and disposition.-Hand auger to 20.9 feet; earth socket (excavator) on cable tool rig (power operated) from 20.9 feet to bottom. Drilling begun, October 21 , 1937; completed, December 24, 1937. Driller, W.P.A. crew (by hand); B. J. Thompson, Waco (by machine). Cased with 8-inch pipe lo 20.2 feet; 6 -inch pipe from I 4.5 feet to total depth, with perforations from 88.6 to 99.3 feet and from 108.7 feet to bottom; converted to observation well.

Remarks.-Hole bailed dry December 30, 1937, after casing; waler rose continuously until it reached equilibrium at 19.38 feet below ground level on July 7 , 1938; water very salty; about 10,500 p.p.m. total solids.

$$
\text { (from ficld log, observations, and samples) }
$$

Residual soil and sub-soil, mixed with remnants of terrace alluvium?-

Depth Thickness

Top soil-black, slightly sandy at surlace; gravel senttered over ground surface near by

Sub-soil-dark yellowish brown, becoming more greenish brown with depth; contains small soft, white concretions and occusional rounded quartzite and flint pebbles; dry; very hard

Sandy marl-

Sandy marl-yellow, hard and tough; rich in clay with small spots of gray visible sand; contains white $\mathrm{CaCO}_{2}$ concretions; no pebbles

Sandy marl-..grayish brown; hard and tough; barely visible sand throughout, also in small spot5; marl thinly laminated; many white $\mathrm{CaCO}_{8}$ concretions in upper part; a few pieces hard calcareous sandstone in lower part; no pebbles; dry. 
$\begin{array}{cc}\text { Depth } & \text { Thickness } \\ \text { Feet } & \text { Feet }\end{array}$

Sandy mar]-grayish brown; l-inch layers ol marl containing barely visible sind throughout, laminated rusty and gray, alternating with thin liyers of rusty and gray fine sand; vecasional pieces

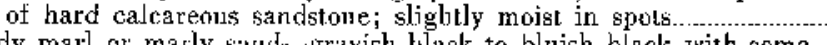

Sandy marl or marly sund. Grayish black to bluish black with some rusty streaks; sofl, friti.le, and somewhat flowy; much sandicr than preceding; not much hard sandstone; slightly moist in spots

Sandy marl-hluc gray, with oceasional rusly streaks; texture and structure generally similar to 9.7 w 16.5 feet conlains pieces of hard, blue calcareous sandstonc up to 1 inch thick; generally dry

Sandy marl--bluish black to greenish black; darkcr, finer', ${ }^{13}$ and richer in clay than the preceding; very tough; eflervesces only

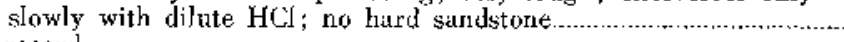

No record

Sandy marl--derk bluc gray, yery sandy, hard (for marl) and compact; pieces of hard sandstone up to 1 inch thick; also some incomplctely ceruented; dry

Sandy marl-dark blue cray, very sandy, faintly ]aminated; visible sund in laminac, small pockets, and distributed throughout; a

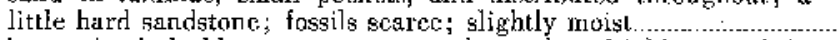

Sandy marl-dark blue gray, very sandy, rather frinble; sand in pockets and lenses, nut distinittly laminated; cffervesces vigorously with acid; slighlly moist.

andy mar]-very dark bluc gray, darker, sandier, and coarser than the preoding; sand in thin laminae and tiny lenses; a little poorly consolidated calcareous sandstone; fossils scarce; very molst

Sandy marl-dark blue gray, very sandy but finer textured and more calcareous than the preceding; gentrally similar to 31.3 to 34.0 feet; a-little hard sandstonc; no fossils; slightly moist.

Ground water appeared in hole after standing at this depth for 40 hours; also every morning thereafter; very slow seepage; water easily removed during operalions.

Sandy marl-dark blue gray, very sandy; distinct laminae of coarser and finer gray sand; also lenses of soft and hard sandstone; slightly moist

Sandy mar]-dark blue gray, finer and more uniform than the preceding; a lew lenses of clean sand; no hard sandstone; very slightly moist

Sandy marl-dark blue gray, still fincr and more uniform; sand just visible; faintly laminated; rich in dccaycd shell fragmenls; dry.

Sandy marl-dark blue gray, coarser and sandier than the preceding; very slightiy moist

Sandy marl-blue gray, similar to 57.2 to 60.8 feet; sand just visible:

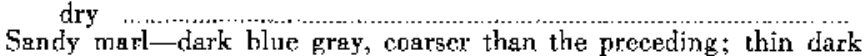
gray and light gray laminae, the latter richer in sand; a lew decayed fossils; slightly moist

Sandy marl-dark blue gray, gradually becoming finer downward; a little soft and hard sandstone; very few fossils; dry....

Sandy marl--dark blue sray, alternating layers, from ahout 6 inchcs to 3 feet thick, of coarser and finer material; the coarser layers carry pockets of coarser sand (moist) and lamina of finer sand (dry) and are more calcareous; the finer layers (dry) carry barely visible sand and are nore uniform; occasional hard calcareous sandstone up to $2 \frac{1}{2}$ inches thick; occasional shells, including Inoceramus, and shell fragmente.

Sandy marl-blue gray, fine grained and compact, fairly uniform, indistinctly laminated, not very calcareous, a little hard sandstone, numerous fossil fragments, dry...

Sandy marl-dark blue gray; altenating thin layers and laminge rich in cosser and finer sand; coarser layera slightly moist, the remainder dry; a little hard sandstone; fossils scarce

Sandy marl-dark blue gray, generally similar to 76.8 to 98.3 feet; alternating thick, indistinctly laminated, coarser and finer layers, the former carrying pockets of moist, coarser sund; occasional thin streaks of hard calcareous sandstone; occasional shells and shell Iragments; gevierally compact and tough...

${ }^{13}$ The terms finer and coarser as used in this deseripilon ure redativa; actually nove of the kand deacribed is any coarber that merlium sand $(0.25$ to $0.50 \mathrm{~mm})$, and moat of it is liner. 
Depth Thickness
Feet

Sandy marl-dark blue gray; distinct coarser (light gray) and finer (darker) laminte, the former more calcarcous; also pockets of grecnish-gray, still coarser sand, which are moist; no hard sandstonc; very few fossils; compact

Sandy marl-dark bluc gray, similar to preceding but finer; sand barely visible except in coarser laminate and pockets; very little hard sandstone; some lossils; hard, compart, and tough...

Sandy marl-dark blue gray; more ar less distinct coarser and finer laminae, many of them composed of thin sheets of hard or soft calcareous sandstone, texturc in general very fine; very few fossils; generaily dry

Sandy marl-dark jlue gray, a little coarscr than the preceding; distinct laminae and also packets of coarser sand, which are moist and taste salty; a few laminae of hard sandstone; fossils suacte; most of material dry

\section{HOLE 1020}

Location.-Falls County. Jose Maria Sanchez survey; on chalk ledge in bed of Brazos River, on the right (southwest) side of the low-water channel, just below the lower of the two sharp bends below the mouth of Perry Creek; about 4 miles southwest by south from the courthouse at Marlin. Landowner, J. E. Masters. Elevation of ground surfate, approximately 321 feet; total depth, 17.5 feet. Diameter, 6 feet.

Method and disposition.-Dug by hand. Well begun, April 21, 1938; completed, May 19, 1938. Dug by W.P.A. crew. Filled.

Remarks.-Constant flow of ground water entered hole through joints in chalk, neccssitating frequent pumping during cxcavation work; after standing 16 hours, water level in hole was usually 2 to 4 feet higher than in adjacent Brazos River.

Iـog

- (from field log, observations, and samples)

Depth: Thickness
Feet

Pecan Gap-

Lower chalk-

ChaJk-chietly blue gray, with irregular areas of white to cream color; both herome lighter colored ufter a few hours exposure; hard, compact, fine grained; no grit after chewing

Ground water at 0.5 foot.

Chalk-blue gray, except alang joints, where cream color continues: very hard; not so brittle as preceding; contains patches, sandy in appesrance, whirh scem to be aggregates of microscopir fossils; no grit after long chewing; occasional shells

Chalk-b]ue gray, slight]y coarser than preceding, more brittle, hard, rings under hammer; contains pockets of very fine "sand," consisting chiefly of calcareous shells but ulso a Jittle glauconite and angular quartz; frequent fossils, chieily Inoceramus and Baculites (llattened)

Chalk-wblue, finer graised, harder; gritty on chewing but no sand pockets; glauconite throughout

Chalk-blue, similar to preceding hnt very fossiliferous; numprous shells, casts, and fragments of Inoceramus, Bactites, and others not determined; tlauconite and pyrite (or marcasite)

Contact zone-interbedded streaks of glauconitic chalk and black, moderately soft, silty marl; a lew angular pieces of marl in the chalk and a few lenses of chalk in the marl; sharp contact between the materials in every case $\therefore \quad$ Apprex.

4.0

40 

Depth Thickness
Feet Feet

Wolfe City-

Silty marl-

Silty marl-black, / moderately soft; can be carved by fingernail; breakage somewhat platy parallel to bedding; much invisible silt uniformly distributed throughout (detected on chewing); on drying becomes harder, lighter in color, and tends to chcck and split parallel to bedding; upper part contains numerous cylindrical burrows up to about $3 / 4$-inch diameter filled with glauconitic chalk

Clay-bluish black to purplish blae; soft, contains pyritc (or marcasite) and slickensides; contains lenses of marl; apparently a fault gouge

Silty marl-biack; same as 14.5 to 16.2 Ieet but without chalk-filled burrows; very uniform; fossils scarce. 



\section{INDEX}

Adkins, W. S.: 28

nffinis, Nodosaria: 39,40

agriculture: ?

alluvial deposits : $15-20$

finss: 18

maxis: 17

Recent : 20

americant, Feterostomella: 87

Ammobaculites sp.: 37,89

ammonites: 13 .

antalysee, cherwical: 23,25

conclusions from: 26

insoluble revidue: 25

mechanical : 23,25

Anomalina henbesti: 37,89

arcat, Globutruncana: 3?, 39, 40

Arkansas: 15

a.siper, barulites: 18

auger holes : 7,

Alstin chalk : 28

austinensis, Lurania: 13, 15

Baculites: $13,32,34,42$

Baird, R. W.: ?

Baker, C. L.: 7, 19

barabini, Inccerantus erippsi : 13

Bell, A. Henry: ?

Bell Dranch : $3_{2}$;

Counly: 16, 28

Biy Creek : $5,17,29,30,31$

Pecan Gap-Wolfe City contact near: 92

Big Sandy Creek: 27,29

Bigenerina: 39

Black Prairie: 8

Bolivinoides deecrata: 87,39

borings: 8,9

boundary, Fecan Gap chalk-Wolfe City marl : 9

Brnago River: 5 , 29, 81, 82

chrlk in bed of $: 30$

lerraces of: $16-17$

Brubhy Creek : 5

eaptures of hesdwatern of: 9

drainage : 8-y.

terrace alluvium : 17-20

Bryan, C. S.: 7

Bryan, Frank: ?

Bulimina: 87,89

hulletta, Dorcthia: 37

burditt marl: 28

calcareous mar1; 8

Pecan Gap member: 14, 31

calcium carbonate content: 21

capture of headwaters of Brushy Creek: 9

earbomate rontent: $11,12,18$,

Cassidulina: 37

Catalpa soils: 22

central Texas, Taylor marl members in : 28 chalk: \&

in bed of Brazos River: 30

Pecan Gap momber: $2 B_{-33}$

$\rightarrow$ ilty mari contact: 29,32

upper, Pecan Gap mernber: 14-15

zones nesr lott: 32

chemicgl gnalyses:

procedure used: 23

christneri, Kyphopyxa: 87,89

Clavulina triangulata: $37,39,40$

clay, Houston blacte = 16

climates:?

Collin County: 38

colluvial devosits: 15-20

conchoidal freteture: 21,28

conchotial Iт:Ae

concretions: 22

conservation survey map: 2 I

contace, chalk-sility murl $: 29,32$

Pecan Gap-Wolfe City : 29, 30, 32 cooperators: 6

cretace, Diploschizt, zone: 30, 31

Globigexina : 37,39

minor, Diploschiza: 15,81

Gretaceous system : 8

crippsi, Inoceramus: 13

Cruckett soils: 22

cruckett
Dane, C. H. : 12,28

deesyed rocks and goils: 21-22

decorats, Bolivimoides: 87, 39

depressa, Gyroidina: 37

Deusgen, Alexnnder: 16

dip : 27

of strata: 8

Diplosehiza: 22

cretacer minór": 15, 31

zone: 30,31

distribution of reoloric unitg: 3-10

Division of Cotton Trsect Damage: $\theta$

Dorothia binletta: 3 ?

Irainare : 8-g

Durania autinengis : 13,15

Fchinocorys texana: 32

elevations: 24

Filisor, Alva: 28, 30

Futrephocergs: 13

Exogyra ponderosa: $13,16,32,83$

Falls County : $5,16,17,28,82,34$

Jogs of holes: $84-40,42$

Fallg of the Brazon: 29,31

frults, minot: 28,32 .

faunal zones, Pecan Gap : 31

fish terth: 39

Flabellamina: 39

Folk. S.: ?

forsgils: $12,13,15$

in holes 1010 and $1011: 37,39$

mieroscopic: $29,37,35$

fracture, concboidn]: 21

Frondicularia: 37,39

Gnudryinn, : 89

geologic unita, distribution of : $9-10$

geology : 8

glnuenite: 13

clobifers. Guembelina : $37,39,40$

Crlobikerina cretaces: 37,39

Globorotalia michelinifna: 37,39

Globotruncana arca: $37,39,40$

Goldich, S. S.: ?

bravel: 16

terrace, reddish : 16, 17

wround water: 9,27

studies, ohscrvation wells for: ?

Guembelina xlotifera: $87,39,40$

Gulf вeries: 8

Eypurum: 22

Groidina : 39,10

denressa : 37

Haplophrarmoides : \$9

Harmany Hill : 80

haadwrters of Brubhy Crexk, capture of :

besvy minerals: 11

hmbesti, A nomalina: 27, 39

Heternstomelir: 39

americana : 37

Hill, $R$ t $P$ : 16 .

Houston black clay : I5

srayelly phase: 16

-Hunt. goils: 21

soits : 21

Humble Bi] and Refining Company : 7, 29, 37, 89

Hunt soils: 21

Hvdrologje Divjsion : 6

Tnoeramus: 12, 14, 15, 82, 36, 38, 41, 42

cripnsi var. barsbini: 13

insoluble residnes: 23

nnajyses of : 25

"intermediate" rock: 80

Jenkins, D. S.: 7

Krimgodd, D. B,: ?

Kyphopyxa ehristneri: 87,89

Lawhon, E, M.:?

Leon County: 16,19

Limestone Gounty : 28

Little Brushy Creek : 17

logs of holes drilled : $84-43$ 
Lott: 82

chaIk: 28

zones riear : 32

Iower chalk, pasan Gap member : 12-14, 81

Loxostoms: 39

map, conservation surver: 21 topographic: 8

marcasito: 11

Marginulina: 37,39

marl, alluvial : 17

highly caleareous, Pecan Gap member: 14, 31

Marlbrook marl: 15,31

Mariin: 17,81

chalk: 28 , 80

Mart: 5,29

mass wasting : 19

MeLennan County : 5, 16, 28

low of hole in: 40

mesnder scars : 19

mechanical analyses: 25

procedure used : 23

micheliniana, Globorotalia : 87, a9

microscopic fossils: 29

frum holes 1010 and $1011 ; 37,39$

minor faults: 28,82

Natutueh sind : 29

Navasota River: 19

Pecan Gap-Wolfe City contact near 32

Nichols, M. L.: 7

Nodosaria: 37,39

affinis: 39,40

vertebralis : 88

O'Brien, J. T. : ?

observation wells, for ground-water studies: $T$

ostracodes: 39,40

Ostrea : 15

oysters: 40

parent rocks: 21

Pecan Gap chalk-Wolfe City marl, boundary : contact: $29,80,32$

unconformity a 27

Pecan Gap member, Taylor marl: 12-15

cholks: 28-83

divisions of: 31

faunal zones: 31

forgile in hole 1010; 37,39

lower boundary of chalk:?

on ceoloxic map of Texas: 29

samples from : 24

Pecten : 15

Perry : 16

$$
\text { Creek: } 30
$$

phosphatic pebules: 38

Planuling taylorensis: $37,89,40$

Plummer, F. B. : i6

Plummer, Mrs, Helen J. : 7

Poag, J. E. : 7, 35

ponderosa, Lxoryta: 18, 16, 32, 33

Paol Creek: 32

preliminary geologic studies: 7

Pullenía: 80

Pyenodonte:

vogicularis: $15,31,32$

Quaternary grnvel plain : B

Ramser, C, E. "

Recent all uvium: 20

reddish gravel terrace: 16,17

Red River County $\div 29$, 39

red silt terrace: I?

residual soi] : 2

Reynosa formation: 16

Riesel : 5, 16, 28

Robplus: $37,39,40$

taylorensis: $37,39,40$

taylorensis: $37,39,40$

of watershed : $9-28$

Royers chalk: 28

Rolbhuugen, F. W.: 29, 37, 39

Rowise, J. T. ; 82 gamples analyzed, description of : 24

sand : 11

aandistore : 11

sandy marl:

Wulfe City member: $11-12$

Santi, M. G.: 7

Saracenaris: 89

silt terrace, red : 17

silty marl: 8

ehalk contact : 20

Wolfe City member : 12

slopes : 8

small watersheds: 8

Smith, F. E. : 7

soil: 16

Catalpa : 22

Crockett: 22

decayed: $2.1-22$

ercsion: 8, 12

Houston: 21

Hunt : 21

I'rinity : 22

Wilson: 22

Soil Conservation Service: 5

South Carolina: 19

Stenzel, H. B.: 7

Stephenson, L. W.: ?, 28

Stewart, A. J.: 7,2

stone lines: 19

stream flow, grester volume of : 19

strike: 27

structiral festures : $27-28$

Taylar group : 8 marl: 1$\}-1$

members in central Texas: $2 B$

taylorensis, finulina: $37,39,40$

Robulus: $87,39,40$

Texgle, John: $7,28,29,30$

verrace alluvium, Brushy Creek : 17-20 red silt: 17

terraces, Brazos River : 16-17

Tertiary gravel plain : 8

texana, Echinocorys: 32

Textularia : $\mathbf{3} 7$

Thomngon, C. J.: ?

topograpbic mas: 8

topography :

Trading House Creek: 17

triangulats, Clavolina: $3 ?, 39,10$

Trinity soils : 22

Trochammina: 37,39

unconformity, Pocan Gap-Wolfe City ; 27

upland gravels: 8,16

upper chalk, Pecan Gap member: 31

U. S. Bureau of Entomology and Plant Quarantine :

U. S. Coast and Geodetic Survey: 24

U. S. Wenther Burcau : 6

Uvalde County : 16

formation: 16

crrvel : $\mathrm{g}$

vegetation: $B$

Verneuilina $\div 35$

vertebralis, Nodosaria : 29

vesicularis, Pycnodonte: 15, 81,32

Waco: 5,29

watersheds, smalt : 8

well data, hules drilled : $34-49$

wells: 9

Westby, L. A.: 7

Westphaliв: 32

Whitney, F, L, :7, 13

Wilson soils : 22

Wolfe City member : 11-12

bcandary, Pecan Gap chalk : 9

contact, Pecan Gap chalk ; 29, 30, 32

fossils in hole 1010: $\$ 7, \$ 9-40$

sampleg from : 24

Band: 28

zircon: 11 

